\title{
The walls of medieval Zuwila
}

\section{By D.J. Mattingly, ${ }^{1}$ C.M. Daniels, ${ }^{\dagger}$ M.J. Sterry $^{1}$ and D.N. Edwards ${ }^{1}$}

\begin{abstract}
The walls of Zuwila constitute one of the most impressive defensive enceintes among Libyan Saharan oasis towns, but hitherto their construction date has been uncertain. A new AMS radiocarbon date now offers the strongest support for an association with the establishment of the Banu Khattab dynasty at Zuwila in the early tenth century $\mathrm{AD}$, as some previous commentators had suspected. The walls relate to a fortress of approximately 4.5 hectares built on the north flank of an already long-established Saharan town. No detailed account of these walls has ever been published before, though Charles Daniels did carry out a survey of them in 1968 and a summary description was included in the work of the Fazzan Project. Now that these walls can be more securely dated, a full description is merited. The present study is partly based on the unpublished notes and photographs of Charles Daniels. The walls of Zuwila can now firmly be included among Libya's most important medieval monuments.
\end{abstract}

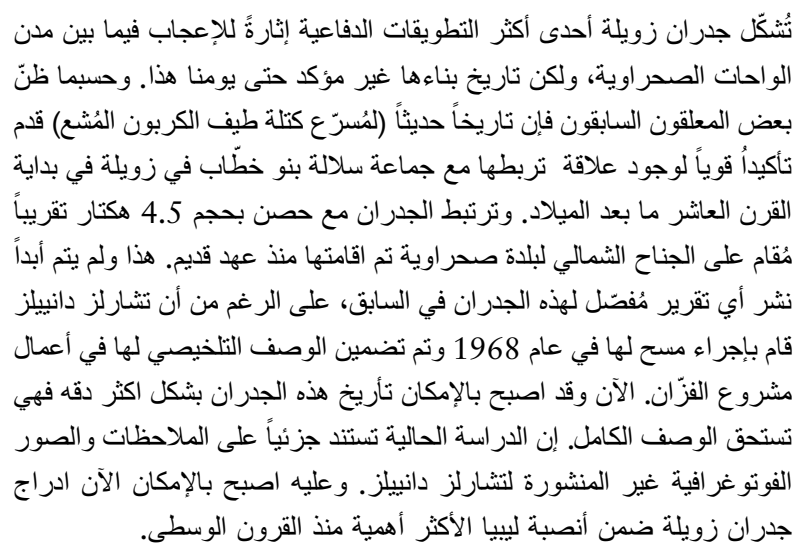

\section{Introduction}

As part of a programme of work on Libya's main oasis sites, we have been reviewing what is known about the archaeology and history of Zuwila (Mattingly et al. 2015). Zuwila is the easternmost major oasis in Fazzan, Libya's south-western desert province (see Figure 1). Although the first historical references relate to the early Islamic period (seventh century $\mathrm{AD}$ ), the origins of the oasis settlement lay in the Garamantian era, probably in the early centuries AD. The site's importance increased through contact

\footnotetext{
1 School of Archaeology and Ancient History, University of Leicester. + Deceased.
}

with the first Arab invaders (see Levtzion and Hopkins 2000, 12-13, Ibn 'Abd al-Hakam; 63, al-Bakri). A treaty relationship seems to have been established at an early date, making Zuwila a favoured node in early Islamic trade networks (the best historical account is Thiry 1995, but see also material gathered in Mattingly et al. 2015). The site became a prominent centre for Ibadi Muslims and, from the tenth to twelfth century, was the capital of the Central Saharan kingdom of the Banu Khattab, controlling much of Fazzan and several crucial trade routes (Levtzion and Hopkins 2000, 63-64, al-Bakri; 122; 129-30, al-Idrisi; 138, Kitab al-Istibsar; see also el-Hesnawi 1990, 27-34; Mattingly 2003, 90-106; 2013， 534-38; Rossi 1968). The Banu Khattab have often been associated with a series of six impressive tombs on the east side of Zuwila, though hitherto there has been no archaeological evidence to prove this.

The Garamantian and early Islamic oasis settlement at Zuwila is now known to have comprised an extensive undefended area of mudbrick buildings around a probable late Garamantian castle (qasr) and the first congregational mosque. On the northern side of this oasis town, a c. 4.5 ha fortification surrounds what still remains of the later medieval and early modern town and has often drawn comment for its unusual pisé construction, unparalleled in Fazzan (see Figure 2). The first published plan of the Zuwila walls appeared in the summary of the results of the first Italian archaeological mission to Fazzan (Pace et al. 1951, 416-19), but it amounted to little more than a sketch (see Figure 3). The most systematic study of the walls of Zuwila was carried out by the late Charles Daniels in 1968, but never published in his lifetime (see interim notices in Daniels 1968; 1989). It was worked up for publication in outline as part of the Archaeology of Fazzān series (Mattingly 2007, 283-85; also Edwards 2001). A different survey of the enceinte also appeared in Abdussaid's short English account of his excavations at the great mosque at Zuwila (1979, 327-29, accompanied by a slightly longer Arabic text [Arabic pages 59-70], 65 photographs, and six foldout plans and section).

Subsequently, we have obtained an AMS (accelerator mass spectrometry) radiocarbon date on a date stone embedded in the rammed earth fabric of 


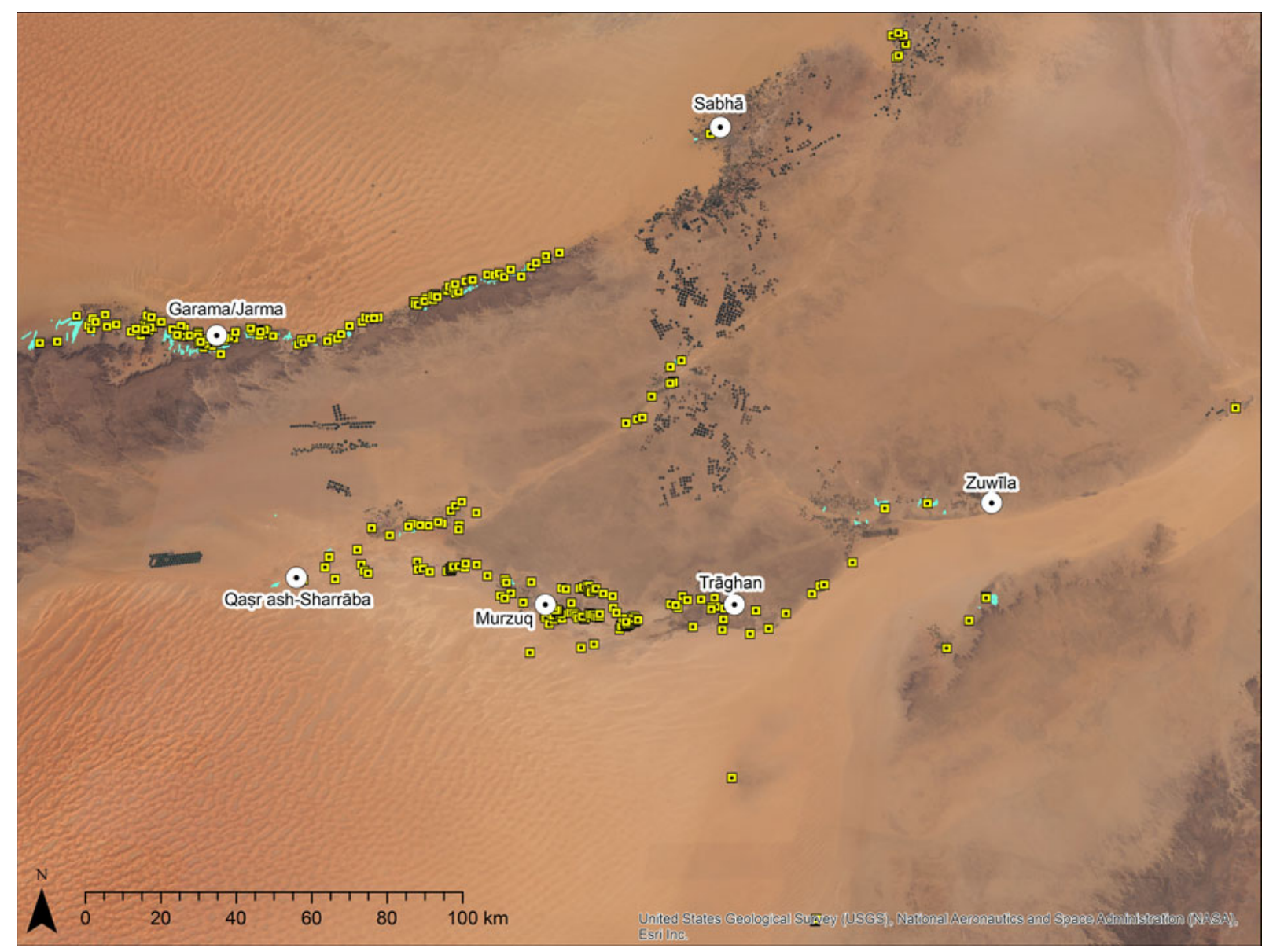

Figure 1. The location of main sites mentioned in the text and Garamantian settlements.

the walls, confirming the association of the enceinte with the Banu Khattab dynasty (see Table 2 below). We shall argue in detail below that the walls were most likely constructed to serve as a fortress alongside the main urban area to the south. The walls have a number of distinctive and unusual features and now that they are scientifically dated it seems worthwhile to publish a more detailed account of them, drawing on the unpublished notes of Daniels and our more recent work. The walls are still fairly intact today, but undoubtedly less well preserved now than they were 50 years ago (see Figures $2 \mathrm{a}$ and $2 b)$.

In the second section of this article, we shall review previous descriptions of and references to these defences. The third and main section will provide a more detailed and well-illustrated account of features recorded by Charles Daniels in 1968. In the fourth section, the dating evidence will be presented and, finally, in the concluding section we shall consider some of the implications of the walls for our knowledge and understanding of Zuwila, the Banu Khattab state and the history of the Libyan Sahara.

\section{Accounts of Zuwila by European travellers and colonial missions}

When the first European travellers reached Zuwila, they found a relatively small village that had largely contracted within the walled enceinte of the former fortress (see Figure 2a), though with some expansion across the north and east walls (for verbatim quotes from the sources mentioned below, see Mattingly et al. 2015). The north-east corner of the enceinte was occupied by a small castle (qasabah). Frederick Hornemann visited Zuwila in 1798 and described it as a town a third of its former size. The reference to the ruins of a large building with very thick walls within the walled area is a clear reference to the existence of the qasabah (Hornemann 1802, 57).

Most early accounts were brief and dismissive. George Francis Lyon, visiting in 1819, also drew attention to the ruins of the castle that 'had nothing to boast of but the solidity of its materials' (Lyon 1821, 217), while Hugh Clapperton's account of the 'castle' conflated the walled town with the qasabah (Bruce-Lockhart and Wright 2000, 59).

In 1914, Corrado Zoli accompanied an Italian military convoy visiting Zuwila. Zoli (1926, 159-60) 

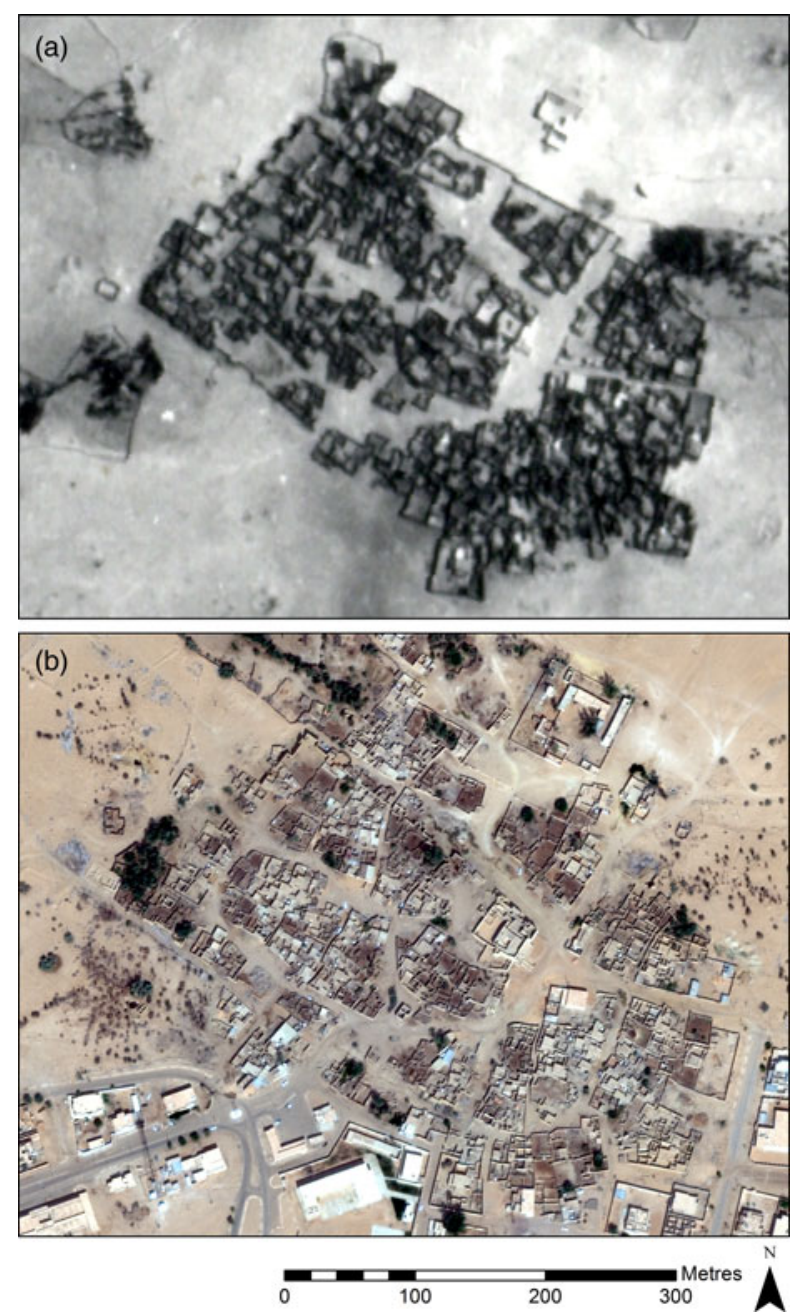

Figure 2. Remote sensing imagery: a) aerial photograph of Zuwila in the 1950s, showing the village still partly defined by the ancient walls; $b$ ) satellite image (Worldview-2) from 2011.

clearly believed the enceinte to have been rectangular in plan, Roman in date and constructed with large quadrangular blocks. The association of the walls with the Romans by Zoli and some of the other Italian visitors reflects a blinkered vision of Libya's medieval period by the modern colonial regime. The earliest archaeological fieldwork at Zuwila was by Caputo in October 1933 (Pace et al. 1951, 41619). Although only a note, this provides the earliest plan of the walls of Zuwila. The Italian plan is similar to those of Daniels and Abdussaid (see Figure 3), though curiously missing all trace of the towers and curtain on the south side. While the tombs were ascribed to the Banu Khattab, Caputo pointed to similarities with Byzantine architecture for the walls (Pace et al. 1951, 417-19). Two other Italian accounts of the 1930s mention Zuwila, with some overlap in their details (Gigliarelli 1932, 141; Scarin 1934; 1937a; 1937b, 637-38).

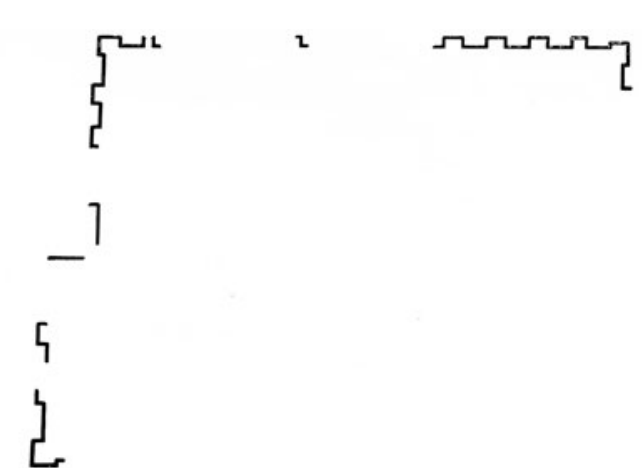

Caputo
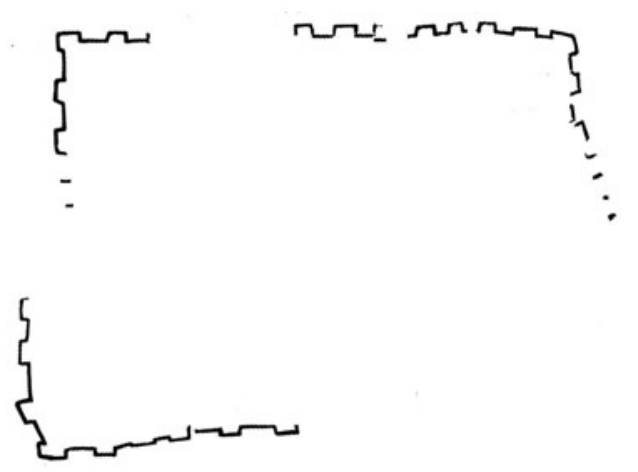

Daniels

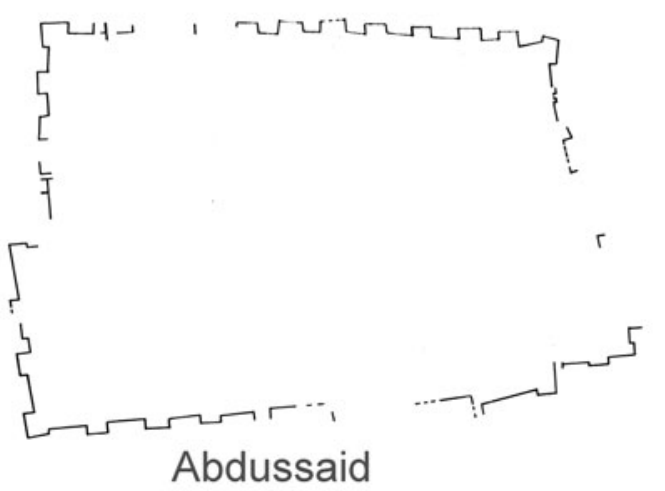

$\mathrm{N}$ Survey $\mathrm{N}$

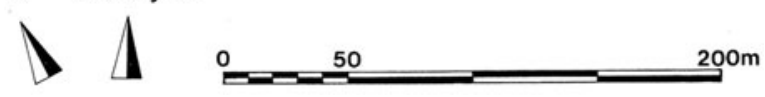

Figure 3. Caputo's plan of the walls of Zuwila, at the same (approximate) scale as those of Abdussaid (1979) and Daniels.

A French Mission in the 1940s noted that Zuwila had contracted from an original open and extensive settlement to a tiny village huddled within a strong enceinte of pisé construction, pierced by four gates (Despois 1946, 103-104). In the north-west angle of the fortified town was a small fort (the qasabah), which Despois credited to the Turks, with further adaptation by the Italians later. Some further brief notes on the archaeology of Zuwila were published by Ziegert (1969), though adding little to previous 
accounts of the walls. Subsequently, there have been some excavations of the early Islamic mosque, which lay just to the south of the walled enceinte (Abdussaid 1979; Ziegert and Abdussalam 1973). Abdussaid's comments on the walled enceinte to its north were very brief, notwithstanding the fact that a survey and plan of the walls appears to have been done at this time (1979, 329; see also photos 42-45 and plan).

Like Daniels, Abdussaid started numbering towers from a point near the centre of the south wall, but his numbers were generally one lower than those allocated by Daniels for the same towers (and are not indicated on Figure 3 to avoid confusion with Daniels' numbering shown on Figure 5). He numbered a total of 25 towers (with space for several more in the gaps). Reference will be made to the Abdussaid plan in the account below, where it adds something to the Daniels survey - the major difference between the two plans is in the greater amount of detail mapped for the south-east corner of the enceinte. There are certainly some inaccuracies in the Abdussaid plan and it is possible that some of the mapped elements of towers relate to modern walls that corresponded with the anticipated lines of ancient features. The greater irregularity of Abdussaid's plan of the south-east corner compared with other well-preserved sections is suggestive in this regard (see Figure 3).

\section{The Daniels survey, April 1968}

In 1968, Zuwila was a very small 'town', with most of its single-storey mudbrick houses still contained within the old enceinte (see Figures 2 and 4). The overall shape of the enceinte was presumed by

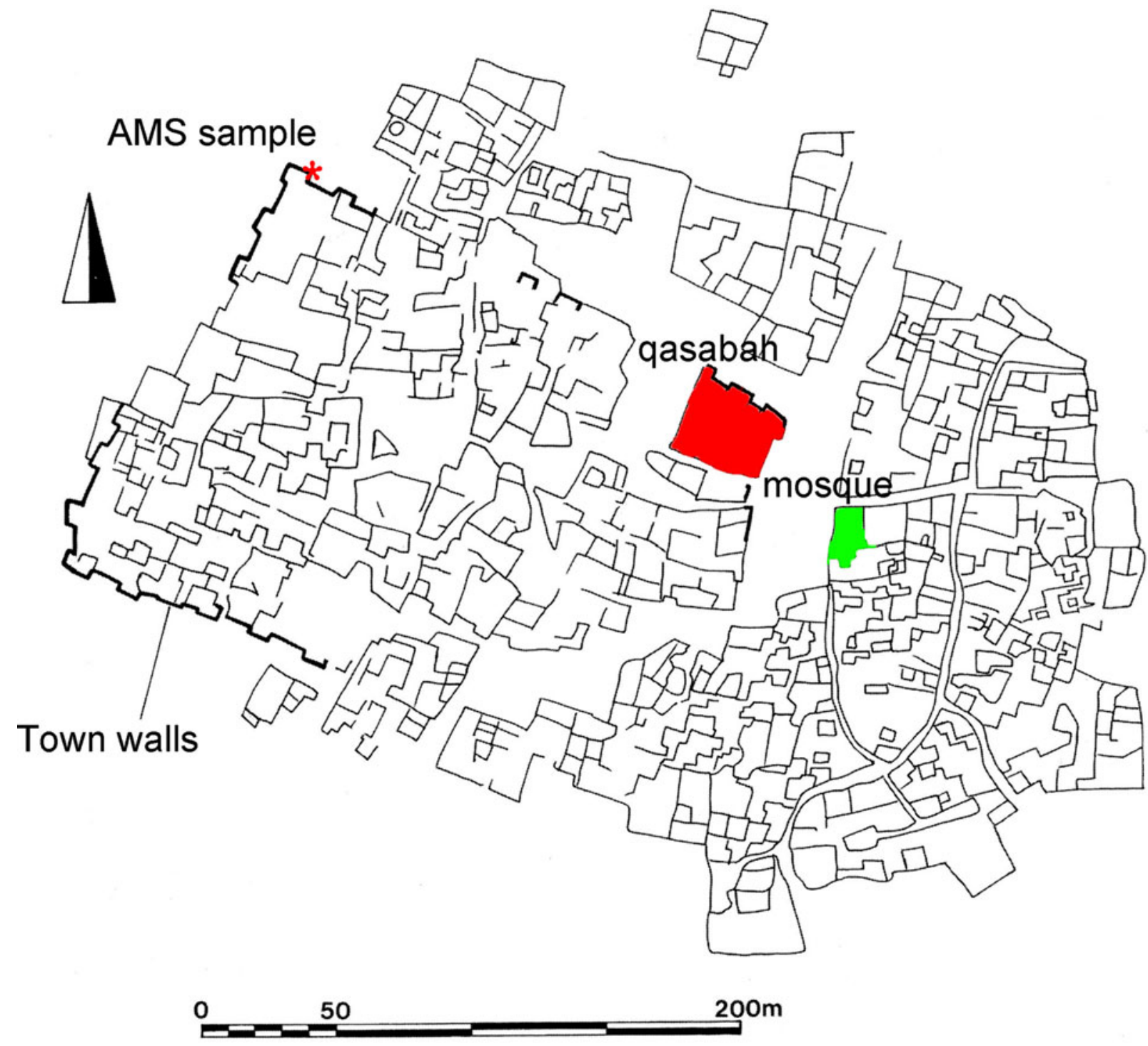

Figure 4. Daniels' survey of Zuwila, showing the enceinte in relation to the early modern qasabah, mosque, and houses. 

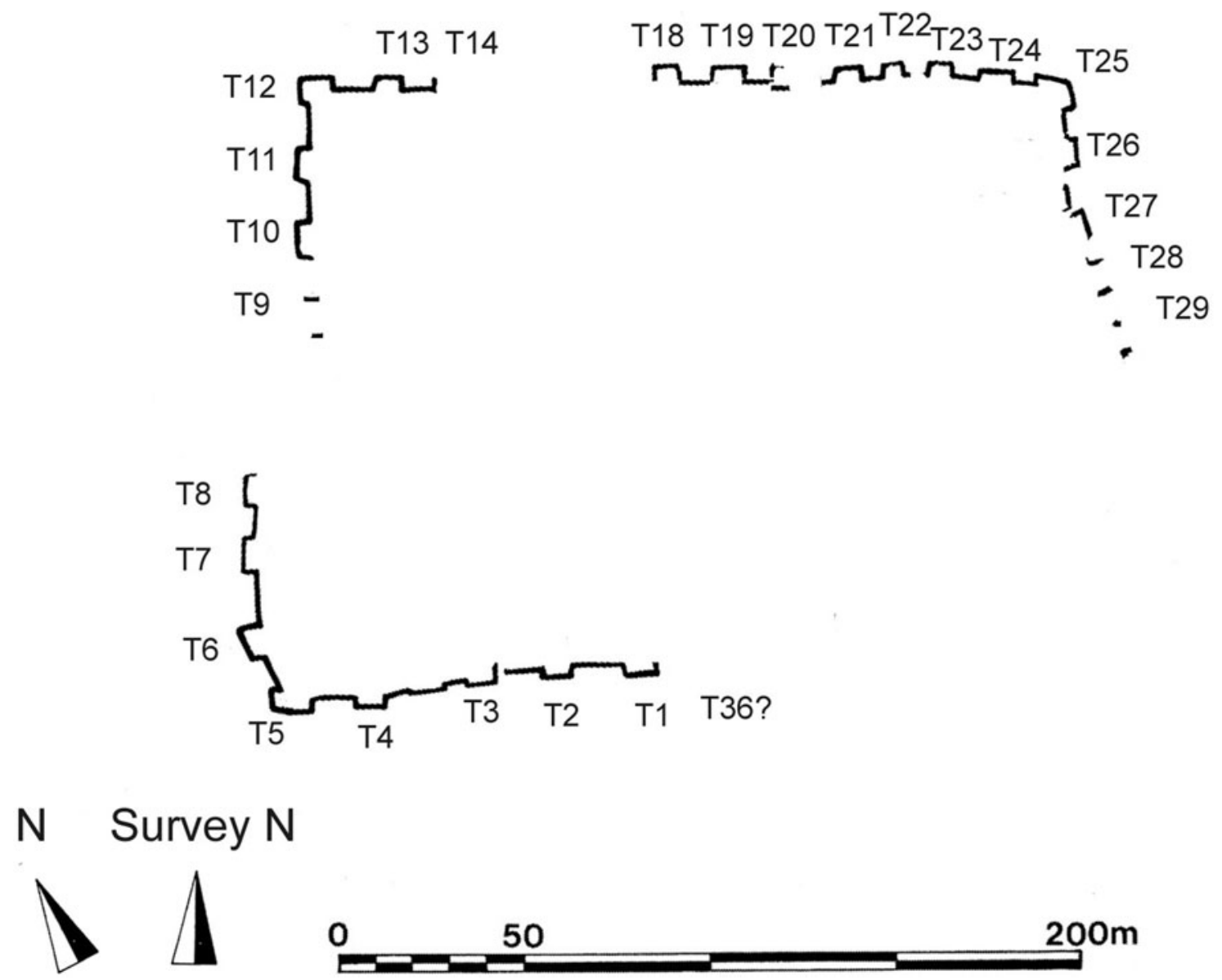

Figure 5. The Daniels survey, with towers numbered.

Daniels to have been roughly rectangular, with the south-east quadrant lost beneath later buildings. However, close examination of the surviving segments suggests that the enclosure may have been less regular. In fact, the fortress/town was roughly trapezoidal, with its north-eastern and south-western sides parallel but of differing lengths $(235 \mathrm{~m}$ and $288 \mathrm{~m}$ respectively) and the north-western and south-eastern walls (189 $\mathrm{m}$ and $150 \mathrm{~m}$ respectively) with regular projecting rectangular bastion towers along all its sides, generally of c. 9-12 m front, projecting 3-4 $\mathrm{m}$ in front of the curtain wall (see Figures 5 and 6). The walls were of very unusual construction for Fazzan, where mudbrick has always been the norm, being formed by the rammed earth (pisé) method. Pisé is, of course, much more common in some other regions of the Sahara, notably in southern Morocco. The original thickness at the base appears to have been about a metre and the total height of the pisé walls was about $6.3-6.5 \mathrm{~m}$, with the sector of the north-east of the enceinte evidently exceeding $7.2 \mathrm{~m}$. There is some evidence for a parapet in smaller mudbrick being erected on top of the pisé wall to add a further metre or more (visible in particular at the north-east and north-west corners). There is no certain trace of a ditch around the outside of the walls, though at the north-west corner there is a slight dip in the ground that is suggestive (see Figure 10b).

For convenience, compass directions used in the descriptions below assume, following the original survey, that the south-west wall faced due south. The wall was only visible for about half its original length on this side and the Daniels survey commenced at the eastern end of this southern wall and continued in a clockwise direction round to the east side of the enceinte. The pisé construction is very distinctive in what at first sight appear to be large square-cut blocks of a gravelly conglomerate (typical dimensions $2.1 \mathrm{~m}$ long, by $0.9 \mathrm{~m}$ high by $0.9 \mathrm{~m}$ deep), on closer inspection were clearly formed in situ by the rammed earth method in short shuttered sections (Figures $7 \mathrm{a}$ and $7 \mathrm{~b}$ ). The material used was a very gravelly sand-mud mix, which had apparently been rammed solid. At various points it was clear that the material had been laid in $0.15 \mathrm{~m}$ layers (Figure $7 \mathrm{c}$ ). Traces of the putlog holes for supporting the shuttering as the walls rose are still 

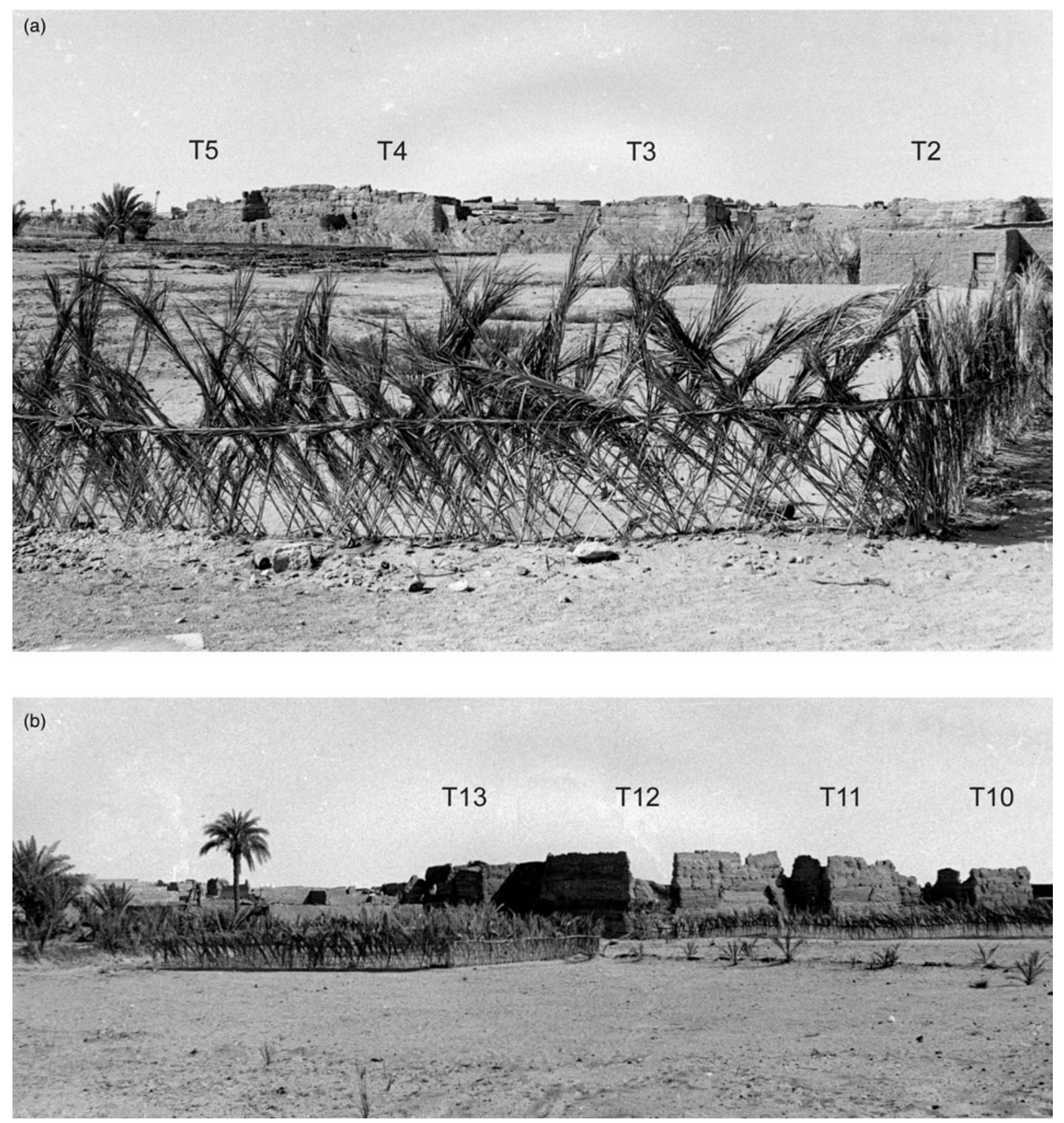

Figure 6. General views of walls of Zuwila: a) south wall, looking north; b) west wall, looking south-east.

visible in many places (Figures $7 \mathrm{a}$ and $7 \mathrm{~b}$ ). These had often been infilled with small stone packing. The maximum surviving height of the walls was seven courses (or c. $6.3 \mathrm{~m}$ ) (see Figure 7a).

About every $10-15 \mathrm{~m}$ along the enceinte there was a rectangular projecting tower. The front and projecting sides of the towers were built with the same style of pisé blocks as the curtain wall between. However, the internal side of the towers was not enclosed by similar pisé construction (for similar configuration of eleventh century pisé towers at Sijilmasa, see Messier 1997, 72). It is inherently unlikely that the rear of the towers was open - indeed, as we shall see, there is evidence to suggest that the lower levels of the tower interiors were systematically infilled with the same gravelly matrix that was used to make the pisé blocks and this indicates that there must have been rear walls in place. The most likely solution is that the inner walls were normally of smaller mudbrick and these have collapsed, been robbed away, or simply not recognised in the survey work. There was evidently considerable regularity in the plan, size and spacing of the towers, with towers numbered by Daniels consecutively from 1 (centre of south side) to 36 (see Figure 5). There are a number of problems caused by his numbering 
(a)
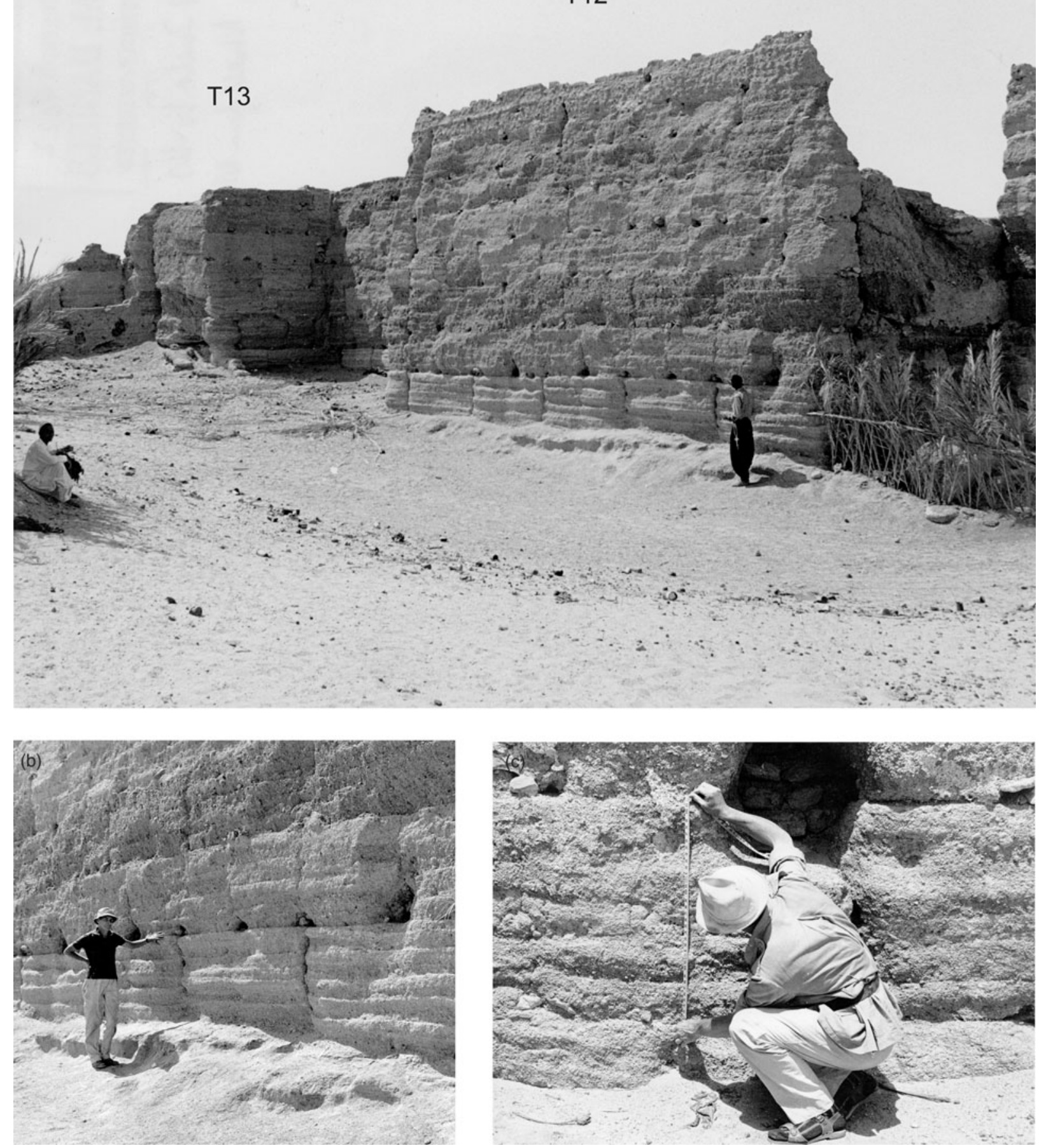

Figure 7. Details of pisé construction: a) north wall, near north-west corner tower 12, showing courses of pisé blocks (note different colour of foundation layers); b) close-up of pisé blocks showing putlog holes with stone lining; c) close-up of internal layering of rammed earth construction for each block.

scheme, which is nonetheless retained here for convenience. He postulated three missing towers in the gap between towers 14 and 18 (though the space may suit two missing towers only) and towers 29-36 were either totally lost or only very vestigial traces remained. There is also a gap between towers 8 and 9 that could have accommodated a further two towers on the west side. The true total was probably 37 or 38 . Abdussaid (1979) indicated 25 towers in his plan, but with space for several more. No certain ancient gates were recorded by Daniels, though we postulate the position of at least one on the north side (see tower 20 below). The Abdussaid plan suggests tower 9 may have been alongside an 
(a)

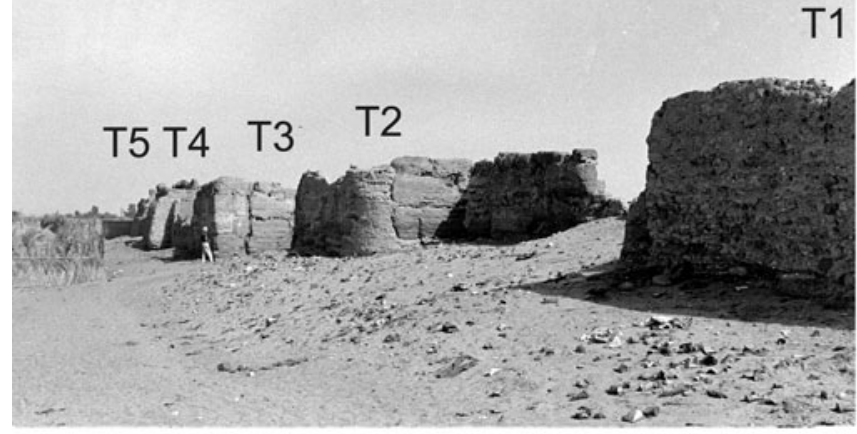

(c)

T4

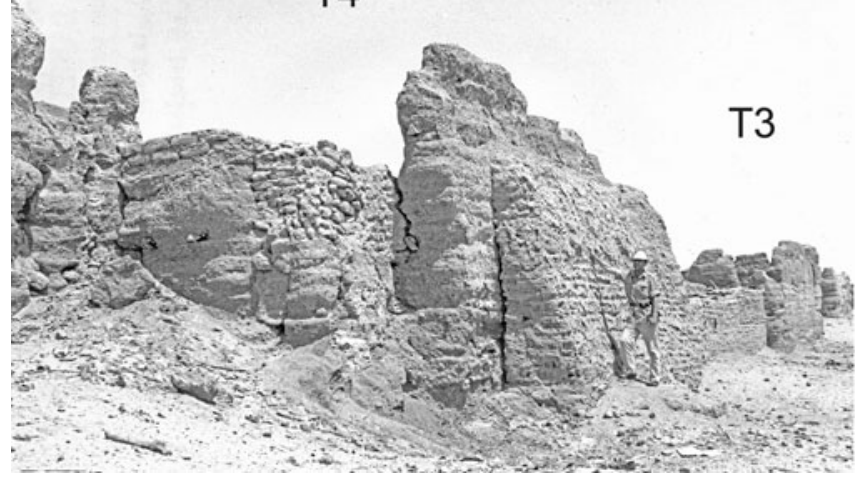

(b) T3
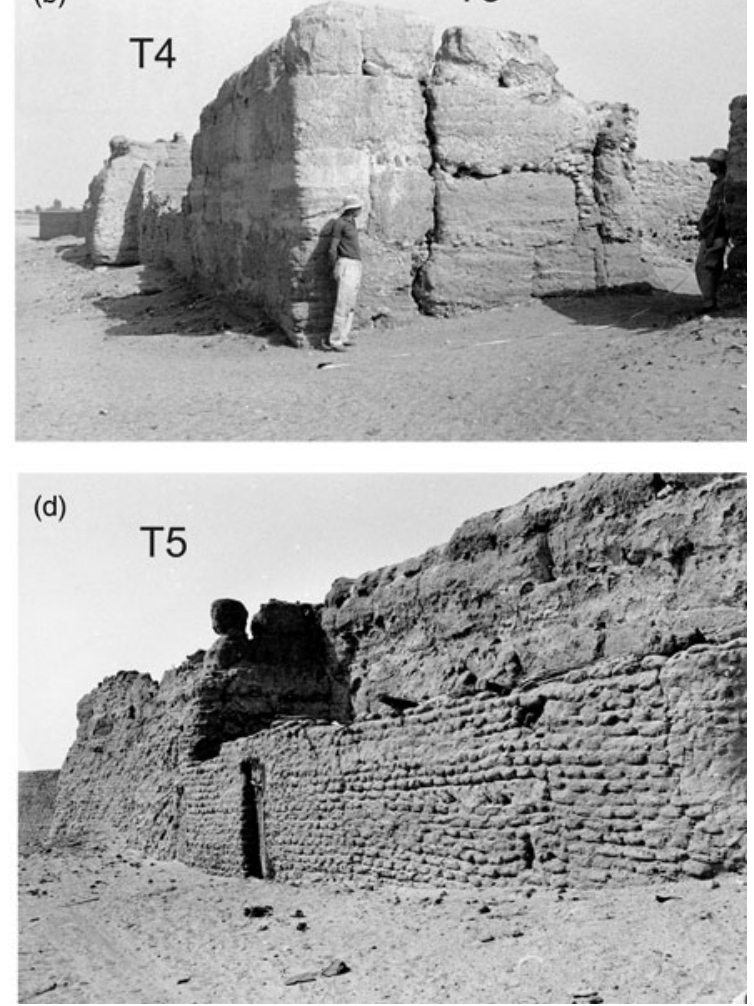

Figure 8. The south walls: a) general view of towers 1-5, looking north-west; b) tower 3, looking north-west; c) tower 4, looking north-east, showing added batter to south side; d) tower 5, to left of modern pen, looking north-west. Note the added batter to south face.

entrance and that tower 26 could have been a gate, and that a further entrance existed near the southeast corner in the south side, though, given the fragmentary state of the traces in that area, this last may be thought doubtful. It is certainly reasonable to suppose that the town must have also had a gate facing the unenclosed town just to the south and additional gates facing east and west are also likely, giving access to the east-west routes and to gardens in those directions. The account below follows the order of survey starting with tower 1 on the south side and proceeding in a clockwise direction.

\section{South wall (Fig. 8)}

Tower 1. Little remained below a later building, but some of the original massive blocks were incorporated into the overlying structure, giving the rough outline (c. $10 \times 3 \mathrm{~m}$ ). The western return wall of the tower survived, as did part of the curtain between towers 1 and 2 .

Tower 2. This stood to $2.4 \mathrm{~m}$ high, with traces of four courses preserved, though the base of the wall was obscured here (Figure $8 \mathrm{a}$ ). Overall dimensions were c. $9 \times 3 \mathrm{~m}$. The curtain between towers 2 and 3 has been replaced by a more recent wall for about three quarters of the length.
Tower 3. Traces of five courses were visible, standing to height of c. $4.5 \mathrm{~m}$, with a footprint of c. $9 \times 3.5 \mathrm{~m}$ (Figures $8 \mathrm{a}$ and $8 \mathrm{~b}$ ). Some small-stone packing noted in putlog holes and along 'seams' between blocks. There was a small cut in the curtain wall directly to east of the tower, giving access on to an internal street. This was probably a secondary postern gate (Figures 4 and 8b). Between towers 3 and 4, the visible wall was modern, but built in front of traces of the original one.

Tower 4. There was a secondary revetment (batter) built against the south face of this tower and evident patching with mudbrick of the south-west corner of the tower (Figure 8c). Overall dimensions of tower were c. $9 \times 3 \mathrm{~m}$. The curtain between towers 4 and 5 was well preserved, with parts of six courses visible though with a modern pen in front.

Tower 5. This is the south-west angle tower of the enceinte and was discernible in plan (c. $12 \times 5 \mathrm{~m}$ ), though encased in more recent mudbrick construction. Like tower 4, it had a mudbrick batter built against its outer southern face (Figure $8 \mathrm{~d}$ ). A house and garden likewise butted up to the curtain between towers 5 and 6 , but four or more courses were visible. 


\section{West wall}

Tower 6. The first tower to the north of the southwest corner tower on the west side was largely lost, though its southern edge was located. The curtain to the north of this point was visible standing up to six courses high, but was not accessible for closer inspection because of the presence of modern buildings.

Tower 7. This was again not very clear due to modern structures, but part of the north side and a corner confirmed the position. The line of the curtain to the north was hinted by a few blocks, but not absolutely definite.

Tower 8. Only the north wall of tower 8 was preserved beneath later buildings. From this point on Daniels noted a change in alignment, with the next clear stretch of curtain wall set back further to the east. It is not clear whether this was achieved by a step in or by a more gradual deviation, making the overall shape of the fortified enclosure trapezoidal rather than rectangular. Abdussaid's plan shows a large step here, but Daniels had not been able to make out the line of the pisé wall hereabouts. Between towers 8 and 9, a distance of c. $36 \mathrm{~m}$, only recent construction was visible from the west, but traces of the inner face of the wall were noted from the east side. It is likely that two additional towers existed here, not counted into the scheme devised by Daniels.

Tower 9. The rear of the west wall of this tower was also only visible from the east (Figure 9a). Abdussaid's plan suggests a possible gate here, but no trace of the walls he recorded here are visible in the Daniels survey. The stretch between towers 9 and 10 was cut through by a modern house under construction.

Tower 10. This well-preserved tower stood six courses high in 1968 (footprint c. $10 \times 4 \mathrm{~m}$ ), though a house was then under construction against its southern face (Figures 9b, 9c, and 9d). The visible foundation course of the wall here was a distinctive yellow-green and made of fine-grained material, while the higher courses were more brownish and made up of coarser mud and gravel layers (see Figures $7 \mathrm{a}$ and $7 \mathrm{~b}$ ). This characteristic was observed at other points on the north side. There was a visible arched window at a height of c. $2 \mathrm{~m}$ above modern ground level in this south wall, possibly a secondary insertion (Figure 9b). It is surely too low to the ground to have been an original feature. It had been blocked up at some point. The next section of curtain wall to the north was patched with more recent mudbrick, but four courses of the pisé blocks were visible here, with frequent putlog holes blocked by small stones (Figures 9d and 9e).
Tower 11. This was another example of a tower faced with an external batter of sloping mudbrick extending to a height of c. $3.6 \mathrm{~m}$ (Figures 9d, 9e, and 9f). The batter was about a metre wide at the base, tapering towards the top. This is best preserved on the west face, but also seems to have lapped round the north and south sides of the tower. There was again a window-shaped hole punched through the south wall of the tower at a height of 1-1.5 $\mathrm{m}$ above ground level (Figure 9e). This also looks like a secondary feature. The putlog holes on this tower were clear and lined with small stones. There were seven courses of pisé blocks visible, with some smaller blockwork preserved above that, giving a total height to the wall here of about $7 \mathrm{~m}$ (footprint c. $9 \times 3.5 \mathrm{~m})$. The next stretch of curtain was also well preserved with seven courses of large blocks surmounted by additional coursing of small mudbrick (Figure 9f). Again, there was a preserved section of batter added to the front face, extending to the top of the fourth course of large blocks (c. $3.6 \mathrm{~m}$ ).

Tower 12. This was the north-west angle tower and, apart for the northern end of the west wall, which had fallen, this was another of the best-preserved structures, with a footprint of c. $10 \times 8 \mathrm{~m}$ (Figures $6 \mathrm{~b}, 9 \mathrm{~d}-$ $9 \mathrm{f}$, and $10 \mathrm{a}-10 \mathrm{c})$. Here again, there were seven courses of the large pisé blocks, with the lowest course being the finer grained yellowish material and the upper six courses of a coarse brown matrix. This was probably the original height of the wall (c. $6.3 \mathrm{~m}$ ) and this tower suggests that, having risen vertically for four courses, the upper courses were narrower giving the upper wall a slight inward slope (Figure 10a). A thin mudbrick wall adds about another metre to the height, though the date of this addition (primary parapet or later addition?) is uncertain. The courses of pisé blocks were offset alternately in the manner of brick construction (Figure 10a). The interior of the tower, visible at the collapsed north-west section, was filled with layers of coarse material similar to the rammed mud of the pisé blocks (Figure 10a). Given the near intact state of the tower, this must have been a deliberate infill of the lower part of the structure. Tower 13 provides another example of the same phenomenon and shows that this was carried out as part of the primary construction (see below). At least some of the towers were infilled deliberately to a height of at least $5 \mathrm{~m}$, preventing use of the potential accommodation provided by the lower storeys, but providing a platform at the top for observation and fighting, launching missiles at attackers and so on. There were again many putlog holes in the face of the wall, following the horizontal seams between the courses of pisé blocks and penetrating the full width of the wall. Many were lined or infilled 


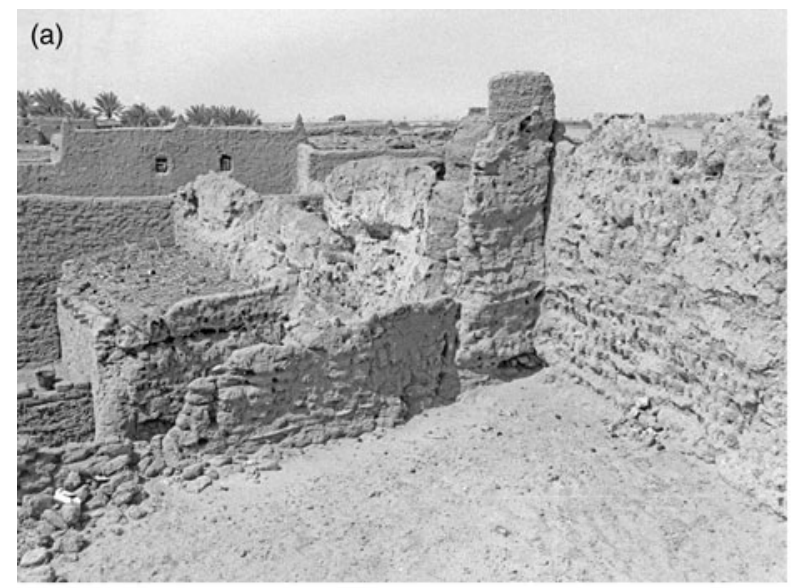

(b)

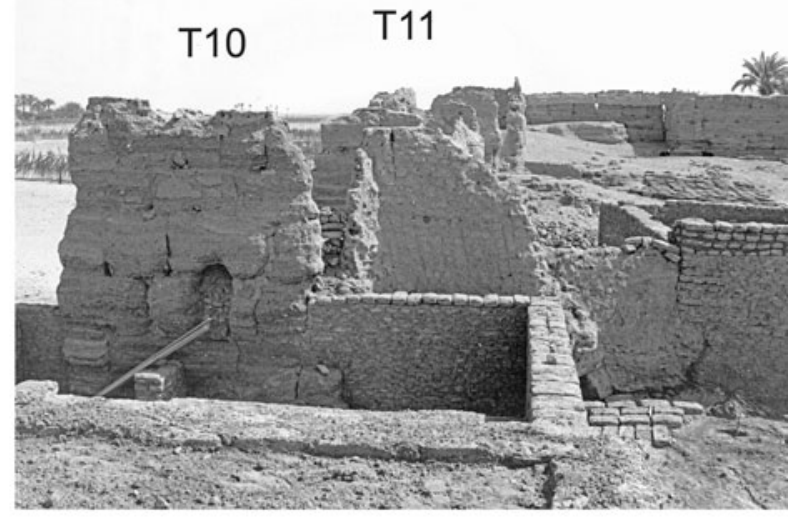

(c)
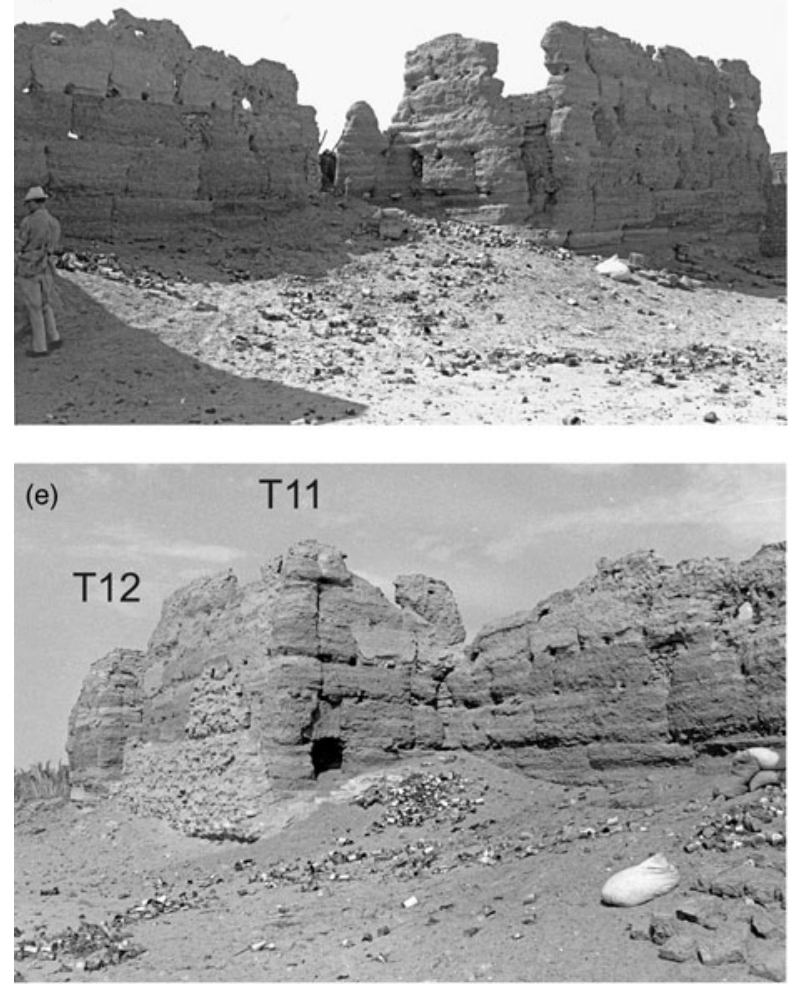
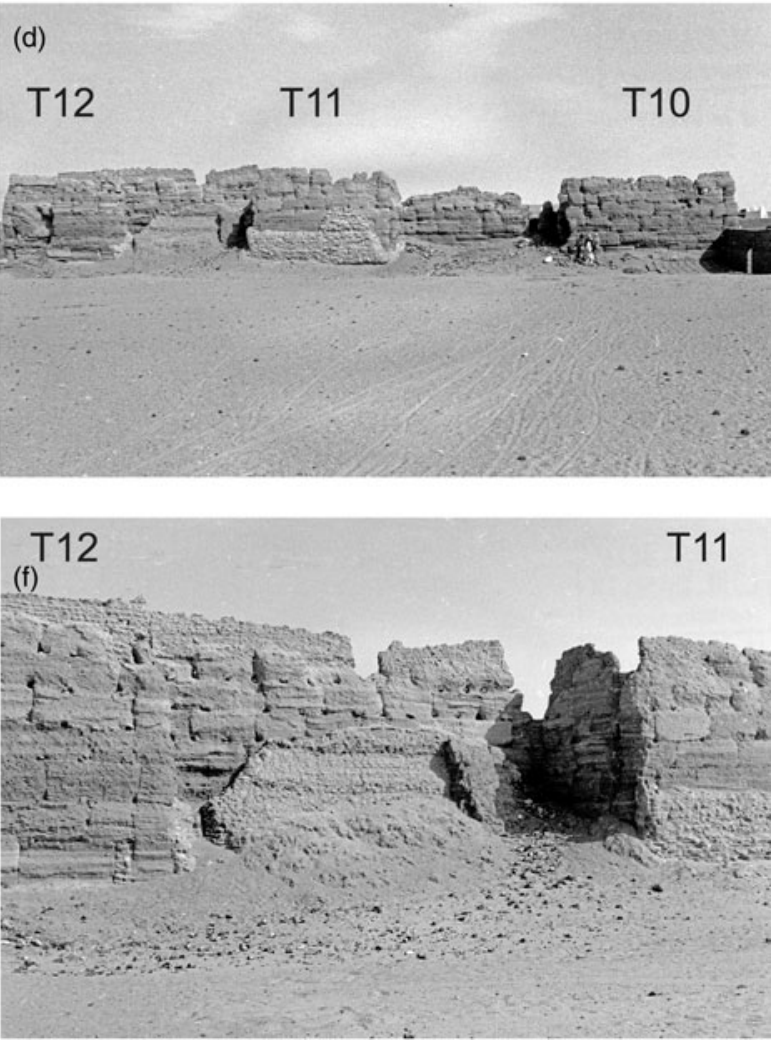

Figure 9. The west walls: a) section of back of tower 9; b) tower 10, looking north (note secondary arched window cut in south side of tower); c) tower 10 looking south-east; d) towers 10-12 and curtain wall looking east; e) tower 11 looking north-east (note added batter to east face of tower); f) batter against curtain wall between towers 11 and 12 .

with small stones. The curtain continues to tower 13 with seven preserved courses (Figure 10c).

\section{North wall}

Tower 13. This tower also stood close to its original height, though its entire front (north) wall had fallen away. This exposed intentionally dumped and tamped down layers of sand, gravel and small stone (essentially the same material used for the pisé construction). It is quite evident that this material is not due to collapse of the structure or to wind-blown deposition - much of the material is too coarse grained (Figure 10d). Some of the material was horizontally bedded and lines up with the level of the pise blocks of the tower walls. That would suggest that the infill was added while the external walls were rising. The vertical gap between the fill and the outer walls of the tower suggests that the wooden shuttering had in consequence been left in place as the internal level rose. There are also some sloping tip lines, but with signs that the material was periodically levelled off. The footprint of the tower was c. $9 \times 4 \mathrm{~m}$. 

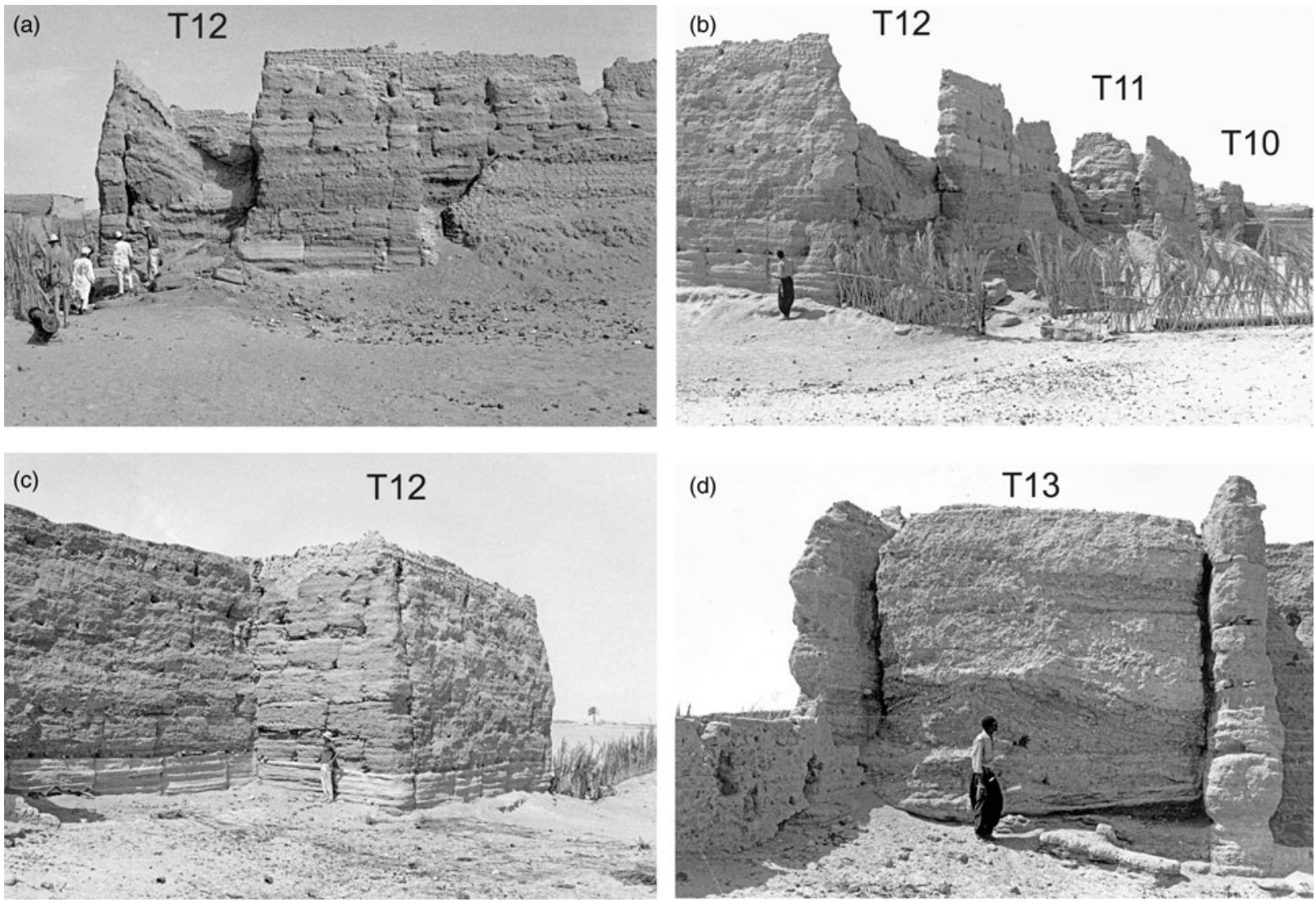

Figure 10. Towers 12 and 13: a) tower 12 looking east, showing internal deliberate fill of base of tower; b) towers 12, 11 and 10 looking south-east (note the dip in the palm fence to right hinting at possible presence of a ditch); c) tower 12 and north curtain wall, looking south-east; d) tower 13, looking south. Note the regular and compacted fill layers inside.

Tower 14. Only part of the west wall of this tower survived, though standing to a height of c. $5 \mathrm{~m}$. Beyond this point there is a gap of c. $46 \mathrm{~m}$ where no traces of the curtain wall or towers were preserved beneath an area of later buildings. Daniels reckoned that three towers (15-17) were missing here, though the actual number could have been only two as the average frontage of a tower and an adjacent stretch of curtain was c. $20 \mathrm{~m}$.

Tower 18. The east wall and part of the north front of the tower survived to full height of seven courses (Figures 11a-11c), giving a footprint of c. $7 \times 4 \mathrm{~m}$. The wall between towers 18 and 19 was slightly less well preserved, but with patching and small mudbrick coursing on top, still stood to about $5 \mathrm{~m}$ high.

Tower 19. This tower stood to a full height of c. $7 \mathrm{~m}$, including an upper parapet in small mudbricks and, though partially obscured at the base by modern houses and pens, it was c. $10 \times 4 \mathrm{~m}$ (Figures 11a11c). The north-west corner of the tower had fallen away but, in this case, there was no surviving evidence of the interior of the tower having been infilled, though it is possible that this had been cleared to allow the breach to function as a passageway between the village inside the enceinte and the early modern quarter that developed to the north of the curtain wall. The curtain wall between towers 19 and 20 survives, with considerable patching adjacent to tower 19 .

Tower 20. This was a very unusual and atypical structure, but sadly very imperfectly preserved. About $10 \mathrm{~m}$ east of tower 19, a fragment of perpendicular wall with the characteristic large coursing ran for several metres north of the curtain (Figures 11c, $11 \mathrm{~d}$, and 11f). However, two further features suggest that this was not a standard tower. Just beneath the modern wall that butts up (from the east) to the north end of the northward projecting wall, there are vestigial traces of several pisé blocks running west to east. On the photographs (see especially Figures 11c and 11d), this seems set back from the expected position of the front wall of the tower. At any rate, the north to south aligned west wall of tower 20 appears to have continued north of the junction. There is also a second west to east pisé block wall that ran to the rear of where the tower should have been, itself stepped back in relation to 
(a)

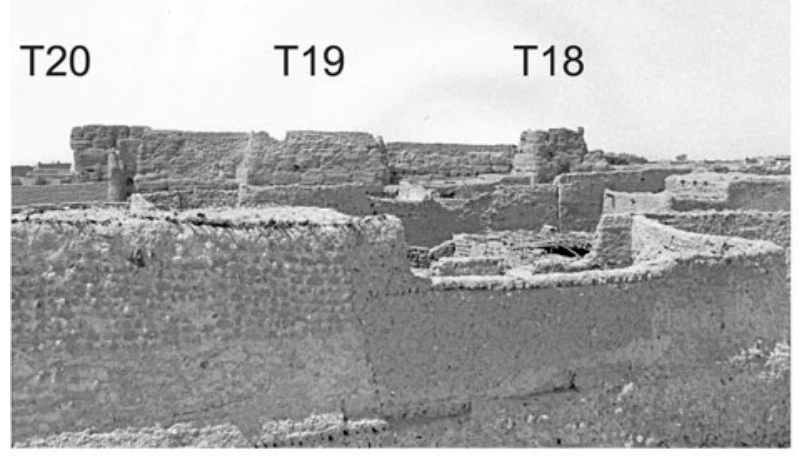

(c)

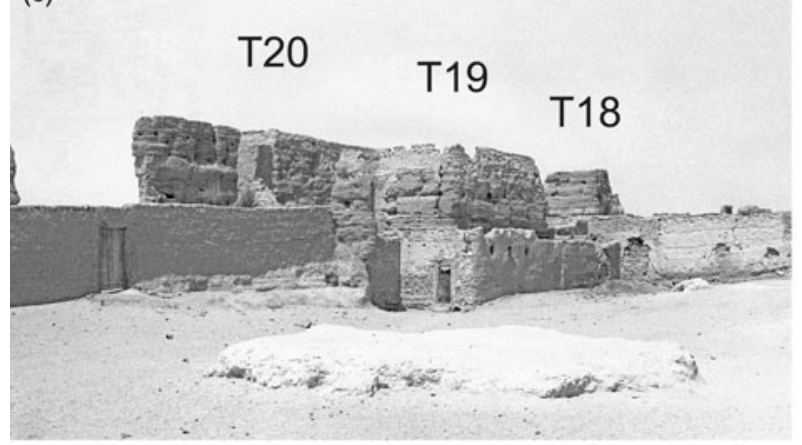

(e)

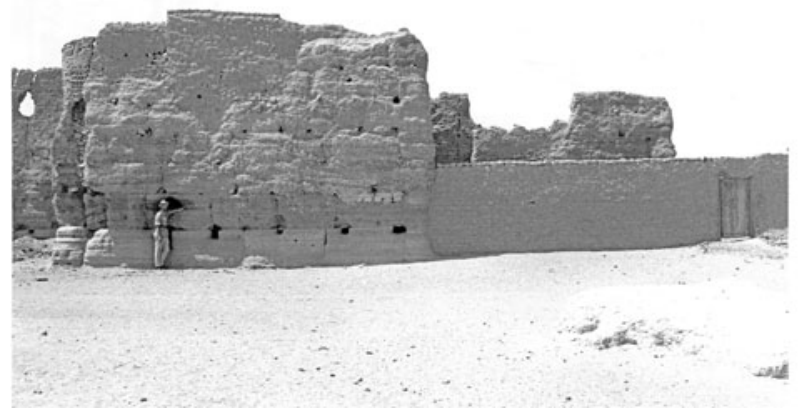

(b)

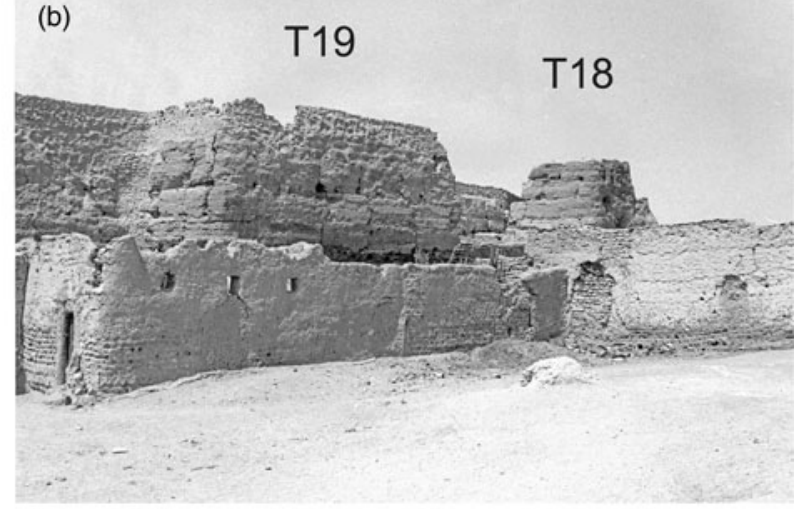

(d)

T20

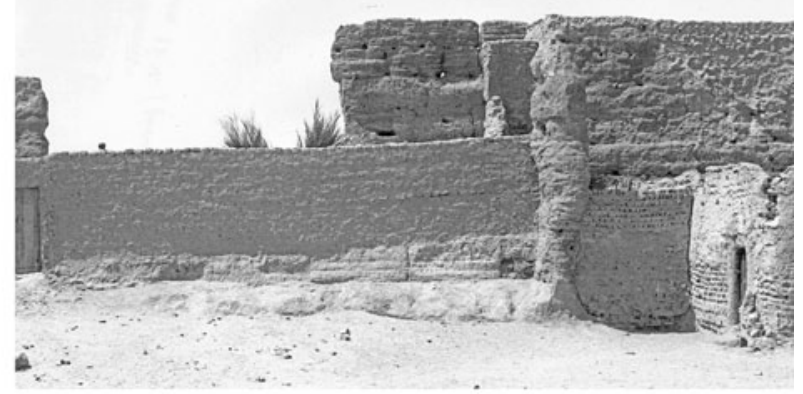

(f)

T21

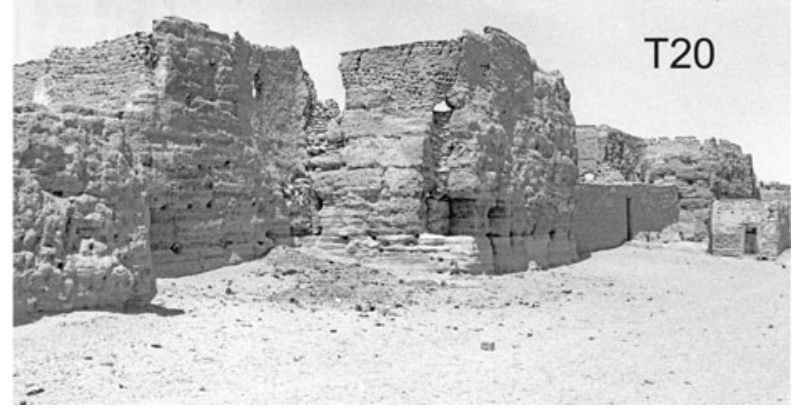

Figure 11. The centre of the north wall: a) towers 18-20, looking south; b) towers 19 and 18, looking south-west; c) towers 20, 19, and 18, looking south-west, with fragments of possible gate tower 20 in the foreground; d) tower 20, looking south, with fragment of north-south wall and traces of a perpendicular eastwest wall; e) tower 21 and fragment of curtain wall to west; f) tower 21 and possible gate 20, looking south-west.

the south of the line of the curtain wall up to this point (Figure 11d). Abdussaid's plan does not include this rear wall, though it is clearly visible in the photographs, and he mapped this as a normal tower which had lost its front wall. Neither point conforms with the evidence. As we have seen, the normal towers did not have a rear interior wall built in pisé blocks, so again it is apparent that something unusual occurred here. The most likely interpretation of these features is that tower 20 was a gate structure, perhaps of barbican type with the actual gate in the east or west side of the projecting tower, and with a more substantial back wall and inner gate fashioned in the large pisé blocks. However, not enough survived to propose a definitive reconstruction of its appearance. There is a small stretch of curtain visible to the east of tower 20 , before the next preserved tower.

Tower 21. This was another quite well-preserved tower, c. $10 \times 3 \mathrm{~m}$, with seven courses of pisé blocks, though patched with rougher mudbrick on the east side and north-east corner. Putlog holes are very visible and those at the lower level somewhat square in section capped with small stone slabs (Figures 11e, 11f, 12a, 
(a)
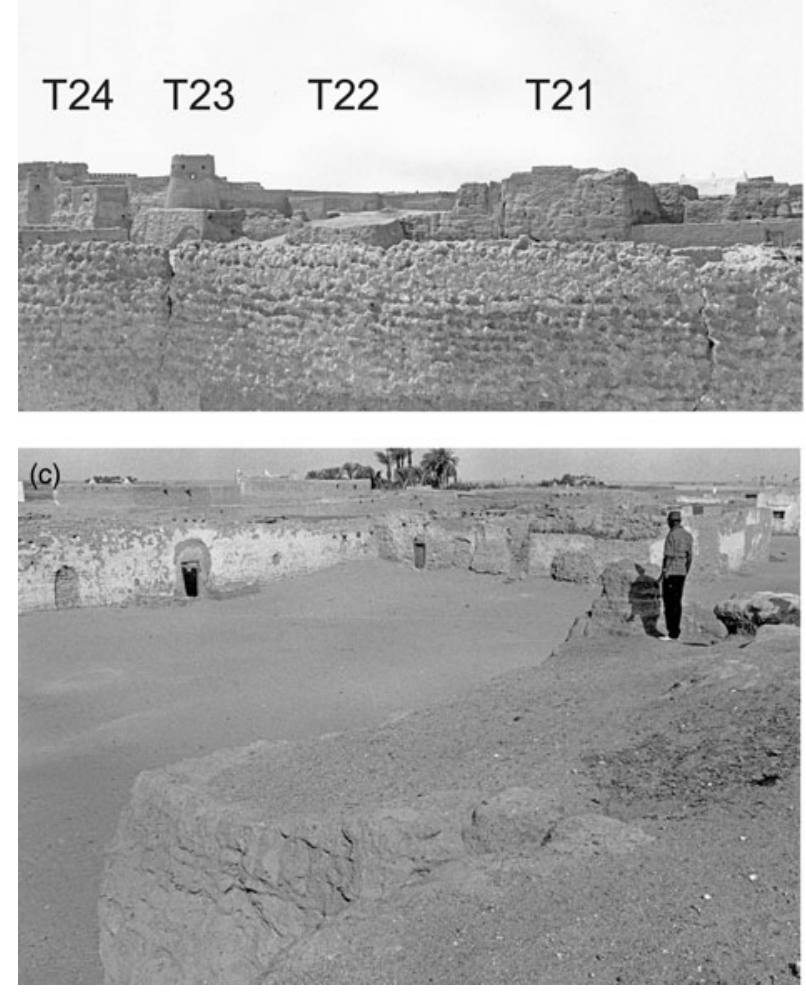

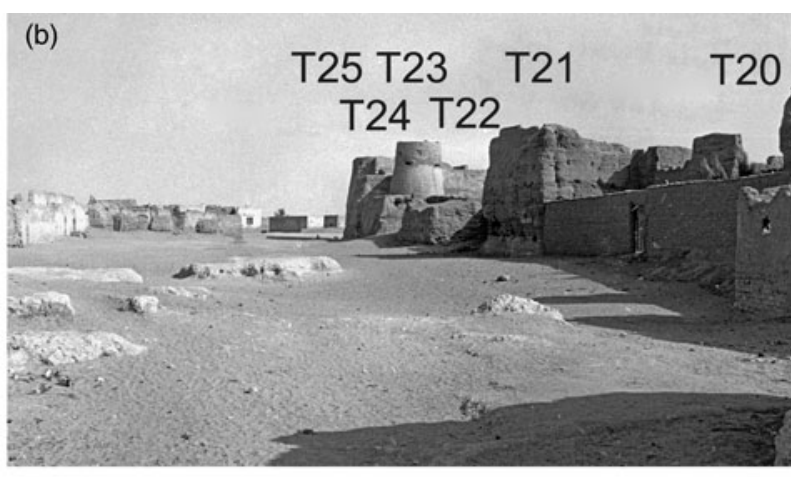

(d)

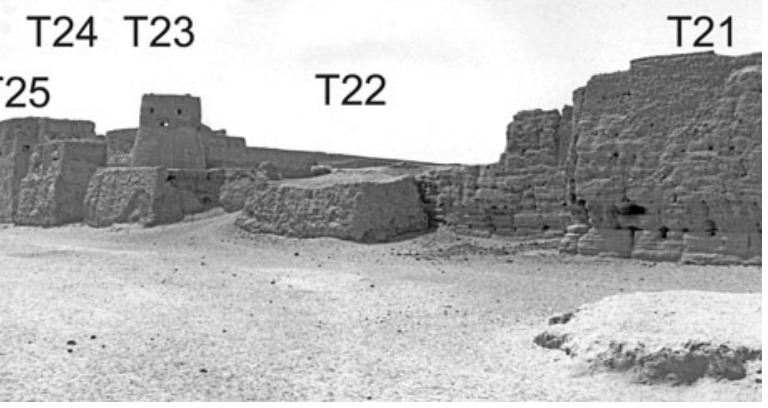

Figure 12. The north side of the qasabah and towers 22-25: a) towers 24-21 looking south-east; b) towers 20-25 looking east; c) platform for tower 22; d) towers 21-25 looking south-west (note the qasabah extends from towers 23 to 25 ).

$12 \mathrm{~b}$, and $12 \mathrm{~d})$. The wall is partially preserved between tower 21 and 22, again with visible putlog holes.

Tower 22. This tower had been truncated to a low platform c. $8 \times 3 \mathrm{~m}$ encased in mudbrick, perhaps the remains of a batter. The pisé blocks below were relatively uneroded here, suggesting that the mudbrick facing had been added at a relatively early date. The projecting mass was clearly the shape and in the position of a missing tower. To the east of this only three courses of the curtain wall survived. There was also a modern break, designed to create a cleared zone all around the qasabah that was built into the north-east corner of the earlier enceinte.

Tower 23. This, like tower 22, was reduced to a rectangular stump, $8 \times 4 \mathrm{~m}$ and about $3 \mathrm{~m}$ high, encased in mudbrick and a large circular tower built on top of it. This circular tower marked the north-west corner of the later qasabah. The exact date of the round tower is unknown. The curtain was visible between towers 23 and 24, with additional brickwork added on top to make up the higher height of the qasabah walls.

Tower 24. The front wall of the tower survived close to its original height, though partially encased in later mudbrick, including a batter. The footprint of the tower was estimated at $10 \times 3 \mathrm{~m}$. The wall between towers 24 and 25 is encased in later construction.
Tower 25. The north-east angle tower appears to have been larger than any of the others $(12 \times 10 \mathrm{~m})$. A further tower has been added directly on top in the early modern period, giving this key bastion a total height of c. $10.5 \mathrm{~m}$ (Figures 12b, 12d, 13a, and 13c). The whole structure has been plastered and whitewashed in its later phases, making it difficult to be certain of the number of courses of the pisé blocks. However, a photograph from 1914 (Figure 14) when the tower had not been refurbished seems to show that there were eight courses originally - making this the highest stretch of the curtain - probably deliberately so (Zoli 1926, f.129). It is possible, therefore, that the later qasabah followed an earlier prestigious structure that occupied this corner of the interior (see discussion below, for a possible interpretation). The curtain wall to the south of tower 25 appears to have been seven courses high, though again the incorporation into the fabric of the later qasabah makes the evidence difficult to read.

\section{East wall}

Tower 26. This tower (c. $9 \times 3 \mathrm{~m}$ ) was incorporated into the main, east-facing, entrance into the later qasabab (Figure 13c). This entrance was pierced through the lower portion of the earlier tower. Abdussaid's plan appears to assume that the entrance here was an original 


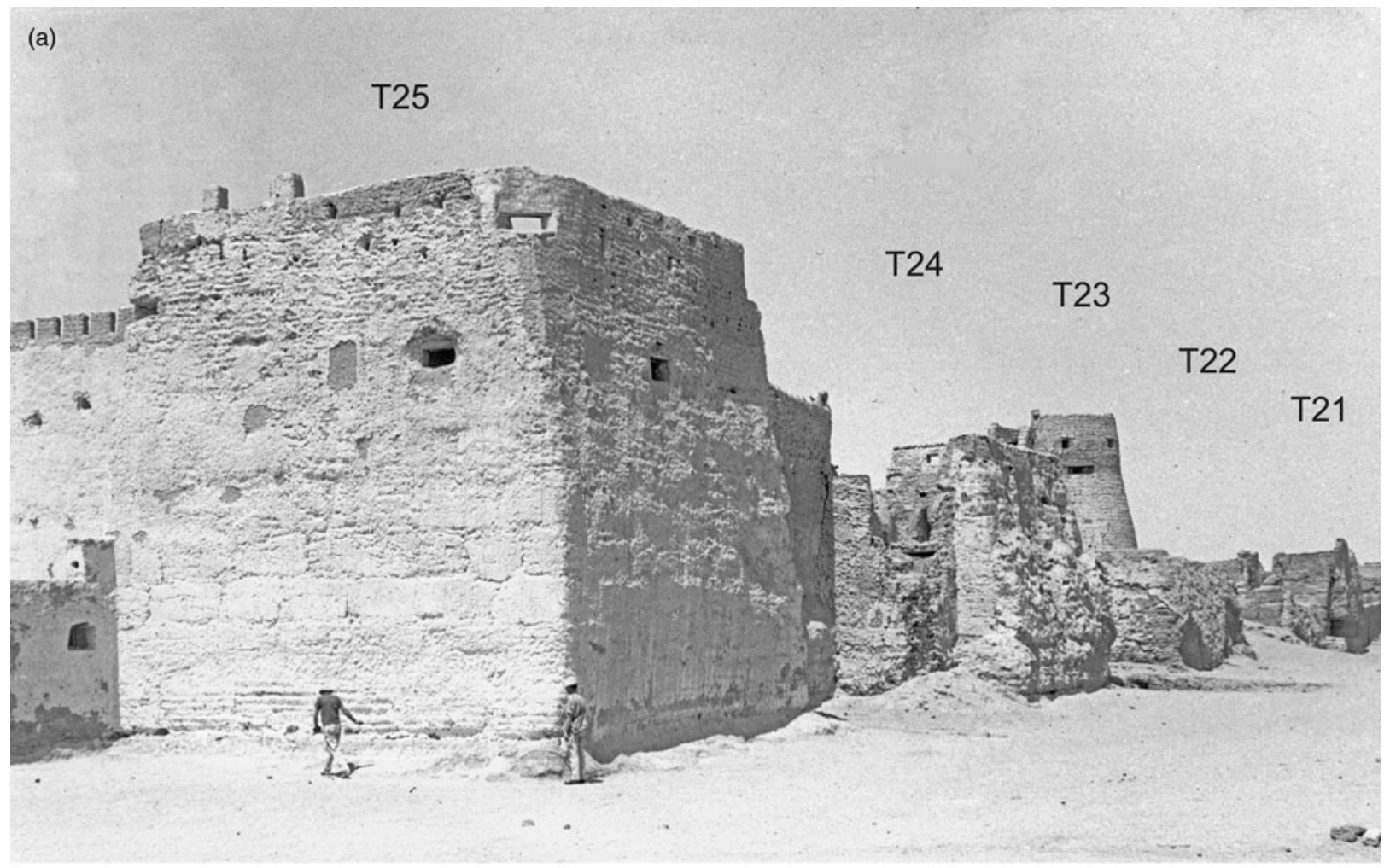

(b)

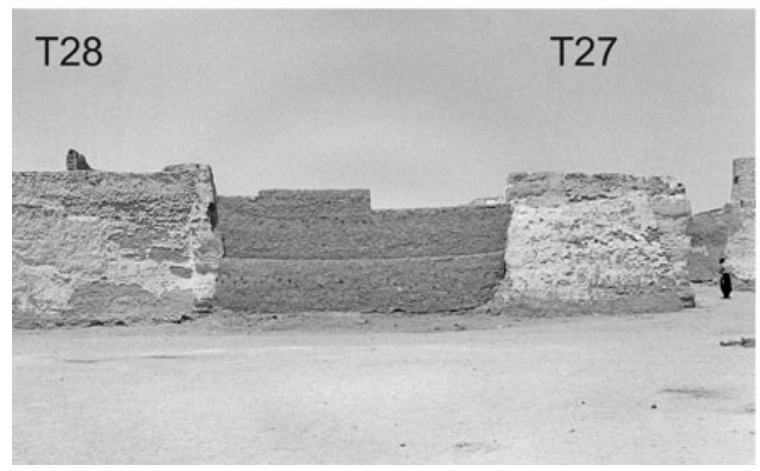

(c)

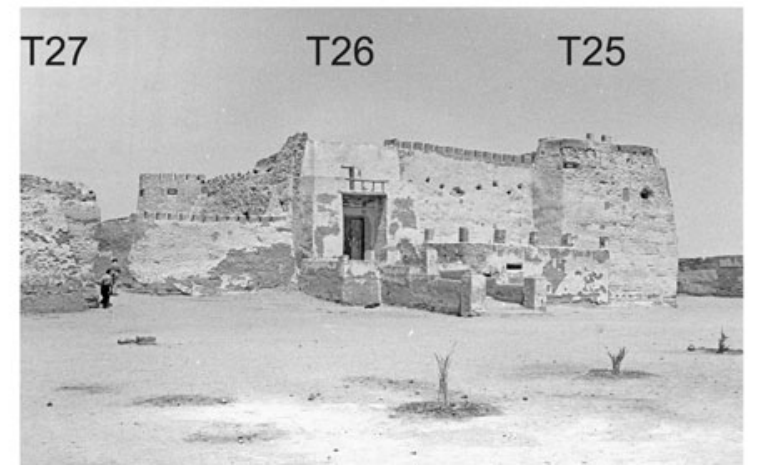

Figure 13. Tower 25 and the east side of the qasabah and east walls: a) towers 25-21 looking south-west; b) towers 28 and 27 looking west; c) towers 27, 26, 25 looking west (towers 25 and 26 form the main east facade of the qasabah.

feature, though it slightly misrepresents the nature of the projecting tower here. The original state of the tower is clearer in the 1914 photograph (Figure 14), which appears to show the collapsed front of a normal tower that was subsequently converted by the Italians into a gateway. The wall between tower 26 and 27 was cut away when the qasabah was isolated from the rest of the town, but clearing a zone all around it in the early modern period. There seems to have been a slight change of angle of the curtain wall around this point, with it stepping out slightly to the south-east and opening up the trapezoid shape to the south.

Tower 27. Although encased in later masonry, the front (east) wall of the tower is partly visible, standing six courses high, with probable original footprint of c. $9 \times 3 \mathrm{~m}$ (Figures $13 \mathrm{~b}$ and $13 \mathrm{c}$ ). The east face was buttressed with a batter. Between towers 27 and 28 a modern house had removed all trace of the curtain.

Tower 28. The east face of the tower had gone, but the ends of the north and south towers are visible, standing five to six courses high and indicating a tower of c. $9 \times 4 \mathrm{~m}$ (Figure $13 \mathrm{~b}$ ).

Tower 29. Beyond tower 28, a few vestigial blocks marked the course of the curtain and, possibly, the north and south sides of tower 29 at about the expected location.

Towers 30-36. These were postulated by Daniels, but little survived. He recorded a few fragmentary traces of the curtain or possible tower walls in 


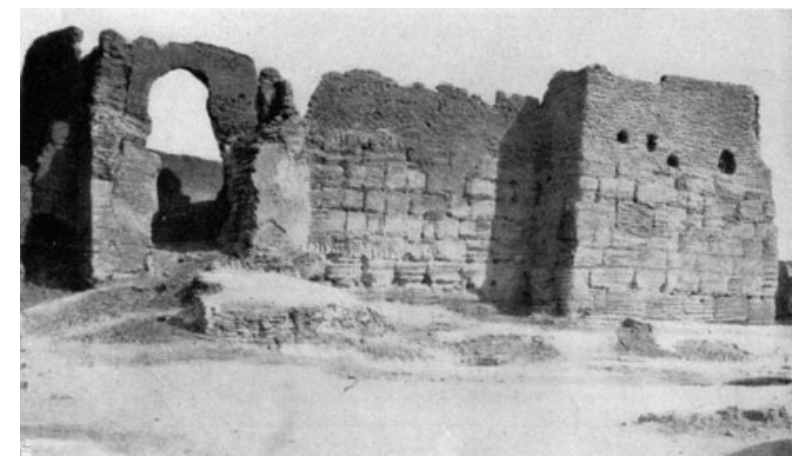

Figure 14. Tower 26 (left) and tower 25 in 1914, prior to the Italian refurbishment of the qasabah (from Zoli 1926).

among the early modern housing that had been built over the south-east corner of the enceinte. He estimated that tower 32 would have formed the southeast angle (Figure 5). As noted already, Abdussaid's plan includes quite a bit of additional detail in this area. While it is by no means clear exactly what he had mapped here, the satellite image (Figure 2b) shows that quite a bit of modern demolition has occurred since the 1960s and this appears to have exposed to view more of the pisé block wall than was visible to Daniels. However, without a further visit on the ground to check the detail, it is not certain that everything on the Abdussaid plan does relate to the walls and towers.

Table 1 - Selected pisé block sizes (in metres).

\begin{tabular}{lcccc}
\hline Structure & Block & Length & Height & Depth \\
\hline Tower 3 & i & 2.17 & 0.82 & - \\
\hline Tower 3 & ii & 2.00 & 0.74 & - \\
\hline 4/5 curtain & । & 1.78 & 0.99 & - \\
\hline Tower 10 & I & 2.22 & 0.84 & 0.89 \\
\hline Tower 10 & li & 2.22 & 0.89 & 0.79 \\
\hline 10/11 curtain & I & 1.95 & 0.74 & - \\
\hline 10/11 curtain & li & 1.48 & 0.89 & - \\
\hline 10/11 curtain & ii & 1.48 & 0.89 & - \\
\hline Tower 12 & । & 2.05 & 0.82 & 0.94 \\
\hline Tower 21 & । & 2.10 & - & - \\
\hline Tower 21 & li & 2.12 & 0.89 & 0.82 \\
\hline Tower 21 & iii & 2.22 & - & - \\
\hline Tower 22 & i & - & 1.04 & 0.94 \\
\hline
\end{tabular}

\section{Further metrical information on the pisé blocks}

Measurements recorded by Daniels of selected pisé blocks reveal something of the variability of the size of formwork used (see Table 1). Lengths varied between $1.48 \mathrm{~m}$ and $2.22 \mathrm{~m}$, with the height of courses between $0.74 \mathrm{~m}$ and $1.04 \mathrm{~m}$, and depths between $0.79 \mathrm{~m}$ and $0.94 \mathrm{~m}$. Taking the average of each of these dimensions, the volume of these consolidated blocks of rammed earth will have been in the order of $1.85 \times 0.89 \times 0.87=1.43 \mathrm{~m}^{3}$. Such blocks must weigh individually something in the region of 1.5-2 tonnes. Although Daniels considered carefully whether these could have been quarried from some sort of conglomerate deposit, his conclusion was that they were formed in situ by compaction of earth, water and lime between wooden formwork. The retrieval of an olive pit from within the matrix of one of these blocks at the north-west corner (tower 12) confirms their anthropogenic origin. The appearance of the wall being constructed in short regular block-like sections, with the visible putlog holes for the formwork, is absolutely characteristic of traditional Moroccan pisé construction (Nami et al. 2014).

\section{The date of the wall circuit and its implications}

Hitherto the discussion about the possible date of the walls has been somewhat deflected by the comment of al-Bakri, writing about 1068 (Levtzion and Hopkins 2000, 63-64):

Zuwila ... is a town without walls and situated in the midst of the desert. It is the first point of the land of the Sudan. It has a cathedral mosque, a bath and markets.

Several new AMS dates are now available based on samples obtained during the work of the Fazzan Project in 2001 (see Table 2). Samples from both the walls of Zuwila (a date stone embedded in a pisé block of tower 12 near the north-west corner) and the supposed Banu Khattab tombs have produced consistent dates at a $95.4 \%$ confidence level to the tenth or very early eleventh century $\mathrm{AD}$ and, at the latest, a generation before al-Bakri's account (see Figure 15). While it must be acknowledged that these AMS dates provide termini post quem for both walls and tombs, the consistency of the three dates suggests close contemporaneity rather than aberrant dating due to long residual organic material being incorporated into these structures. The most plausible interpretation of the evidence is that the tenth-century context indicated fits extraordinarily well with the early Banu Khattab rulers making a series of dramatic architectural statements. Both 
Table 2 - Radiocarbon dates from Zuwila.

\begin{tabular}{llclcc}
\hline $\begin{array}{l}\text { Site } \\
\text { code }\end{array}$ & $\begin{array}{c}\text { Site } \\
\text { description }\end{array}$ & $\begin{array}{c}\text { Sample } \\
\text { code }\end{array}$ & Material dated & $\begin{array}{c}{ }^{14} \mathrm{C} \text { age } \\
\text { BP }\end{array}$ & $\begin{array}{c}\text { Calibrated date range (95.4\% } \\
\text { confidence) }\end{array}$ \\
\hline ZUL001 & Town walls & OxA-26743 & Date stone & $1065 \pm 23$ & $\begin{array}{l}\text { CalAD 900-922 12.3\% } \\
\text { CalAD 948-1020 83.1\% }\end{array}$ \\
\hline ZUL003 & $\begin{array}{l}\text { Banu Khattab } \\
\text { tombs }\end{array}$ & OxA-26745 & $\begin{array}{l}\text { Plant fibres, not } \\
\text { identified }\end{array}$ & $1029 \pm 24$ & calAD 976-1031 95.4\% \\
\hline ZUL003 & $\begin{array}{l}\text { Banu Khattab } \\
\text { tombs }\end{array}$ & OxA-26495 & $\begin{array}{l}\text { Plant fibres, not } \\
\text { identified }\end{array}$ & $1038 \pm 27$ & $\begin{array}{l}\text { CalAD 904-917 2.5\% } \\
\text { calAD 966-1032 92.9\% }\end{array}$ \\
\hline
\end{tabular}

monuments can thus be now fairly confidently ascribed to the Banu Khattab and in all probability (from the date bracket) to the early rulers after the establishment of the dynasty in AD 918. This sort of monumentality is paralleled in other Saharan/ Maghrebian dynastic foundations. The most likely explanations of al-Bakri's seeming oversight are that he was using out-of-date sources for his secondhand account, or that he wrote in all truth of an unwalled town, omitting mention of the walled fortress of the Banu Khattab that had been erected alongside that pre-existing oasis town (Figure 16a).

Al-Idrisi, writing a century after al-Bakri, does not mention fortifications either, but made the following interesting statement (Levtzion and Hopkins 2000, 122):

[T]he town of Zuwila, founded by 'Abd Allah ibn al-Khattab al-Hawwari, who settled there along with his paternal cousins in 306/918-19. The town is named after this man, and it is known by his name [i.e. Zuwilat Ibn Khattab]. This is now a populous town.

We know from other historical and archaeological evidence that Zuwila had been established far earlier than this. One possible implication of al-Idrisi's 'foundation' statement is that 'Abd Allah ibn al-Khattab al-Hawwari was responsible for building something new at Zuwila and that this was subsequently known as 'Zuwilat Ibn Khattab'. The fortress/town described above is a prime candidate and the AMS date fits well with this proposal. The 4.5 ha enceinte could have served either as a fortress or a 'new town' to secure the power of the new dynasty establishing itself a Zuwila in the tenth century AD. There is also an indication that the north-east corner of the fortification may have been built up more from the outset, strongly hinting at the existence of predecessor to the later qasabab in this area - a palace of the Banu Khattab perhaps? It remains unproven, but is a plausible hypothesis based on the evidence. It is certainly not unreasonable to suppose that the Banu Khattab rulers may have established an inner citadel within their great fort at Zuwila.

The dates of subsequent modifications are unknown. The date of the addition of a batter against the external walls is one key change. While this could have been designed to give greater protection to the enceinte against attack at times of threatened siege, this is not necessarily the most plausible argument.

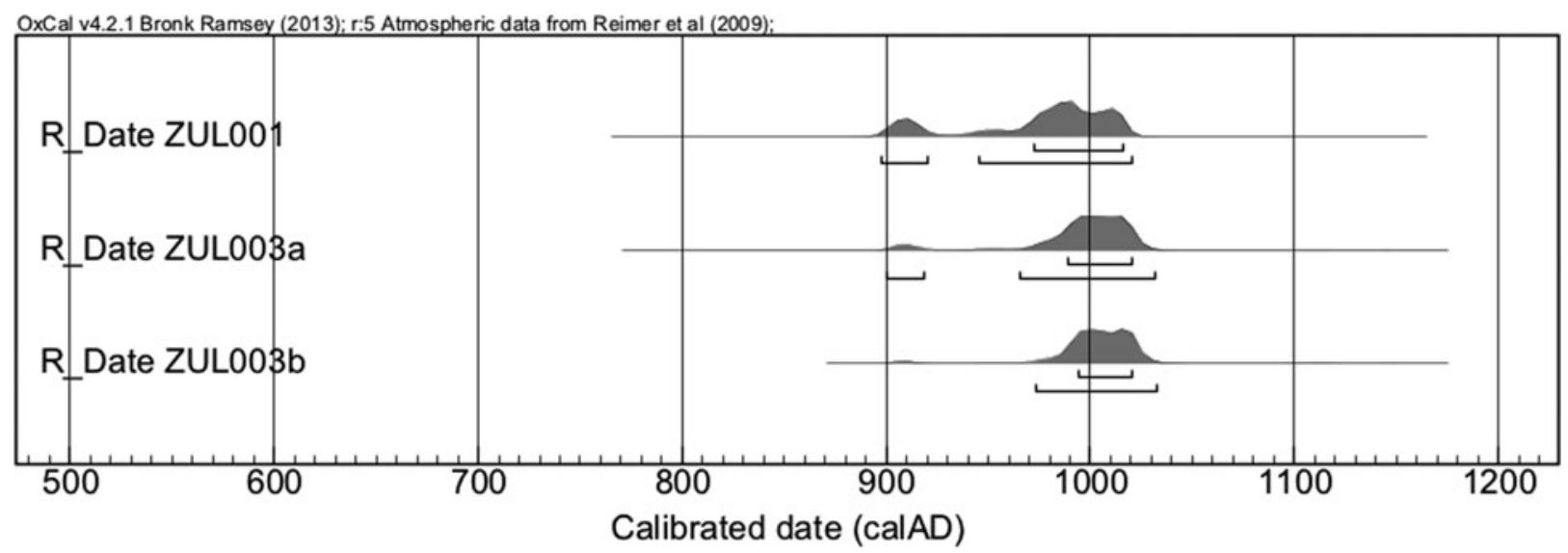

Figure 15. Modelled AMS dates of walls ZUL001 and tombs ZUL003. 
(a)

Zuwila

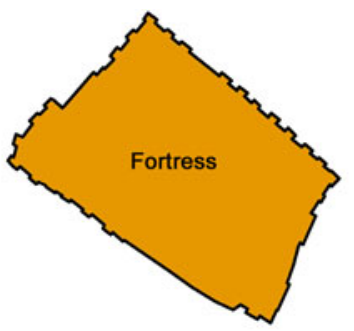

Banu Khattab tombs $1000 \mathrm{~m}$ to east

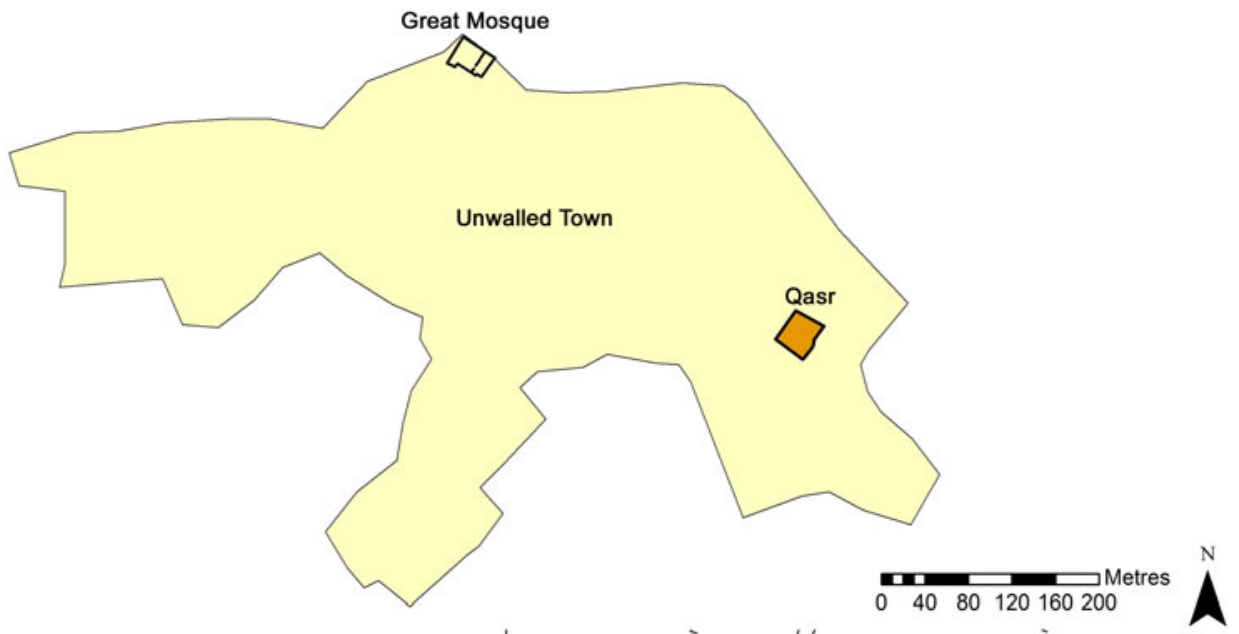

(b) Old Jarma
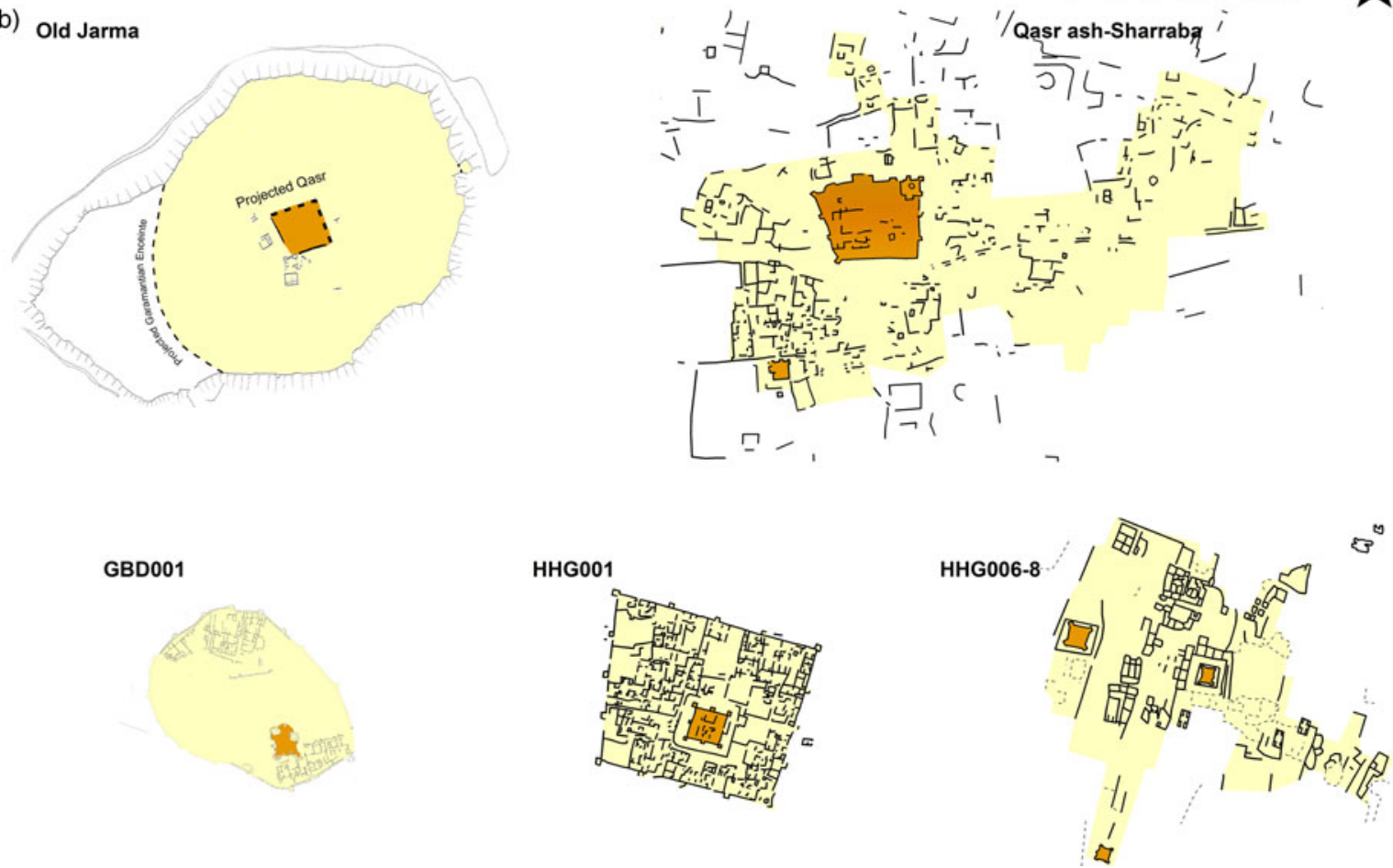

Figure 16. a) Plan of early medieval features at Zuwila; b) Comparative plans of Garamantian fortified settlements: GER001, SCH020, GBD001, HHG001, HHG006-8.

The batter could equally have been intended primarily to buttress sections of the wall that became unstable. It is only preserved in a few places and though it could possibly have been more extensively applied, its subsequent removal from large stretches of the enceinte seems unlikely. At tower 22, the mudbrick facing was evidently added before the pisé blocks had become eroded by the elements. That might indicate an early modification necessitated by structural instability in certain sectors. The 
construction method of the pisé block walls was extraordinary in a Libyan context and would thus have also been technically demanding, when carried to heights of over $6 \mathrm{~m}$, and some of the curtain wall and towers appear to have been built with an inward taper in the upper courses for stability. A few stretches appear to have become unstable (see, for instance, Figures 10a and 10d) and corners and fronts of some towers eventually collapsed outwards. The internal compacted fill observed within several of the better preserved towers could again have been intended to increase the stability of these more vulnerable structural elements. The most likely explanation is that the batter was added, probably from quite an early date after construction, as a means of buttressing the main walls only where instability manifested itself, rather than as a general feature around the entire enceinte. The construction of the batter against the curtain obscured the large blockwork effect that had been so laboriously achieved. That is added reason to see this as a modification that was both necessary and crucial to the continued maintenance of the circuit.

The small mudbrick wall built on the top of the pisé blockwork walls was viewed by Daniels as 'modern', but in principle it is possible that the erection of a narrow mudbrick parapet was quite an early feature, certainly useful once the power of the dynasty started to decline and the small state faced major military challenge from outside powers.

The date at which the circuit was effectively abandoned as an integrated system is also uncertain. The creation of a qasabab in the north-east corner and its isolation from surrounding buildings may from the start have involved the partial demolition of the northern, southern and eastern curtain wall. This did not have the effect of making Zuwila an undefended settlement as the subsequent construction of new quarters of buildings to the north, southeast and east created a new perimeter formed by the outer walls of the new blocks of buildings and new gates (see Figure 4). But the early European travellers quoted above perceived the town as having a walled circuit, albeit a decrepit one, as late as the early nineteenth century.

The traces of 'windows' in at least two towers (10 and 11) on the west side of the enceinte are probably a late feature, indicating incorporation of the towers into houses (and by implication the emptying of the compacted fill from within the footprint of the tower - something that seems to have happened at numerous points around the enceinte). Such measures will have reduced the security of the perimeter and probably post-date the partial demolition of the walls on the north, south and east sides. The limewash plaster that is visible on the exterior of the walls of the qasabah (see Figures 12, 13, and 14) is not preserved elsewhere and seems most probably a later treatment of the qasabah walls alone.

\section{Concluding discussion}

The architectural inspiration for the fortress should be sought either in pre-existing Saharan tendencies or in external influences. From the time of the Garamantes, many villages and urban sites had been fortified by the presence of walled enceintes or fortified compounds within more extensive open settlements. Some of these were not dissimilar in plan to the walls of Zuwila, being sub-rectangular enceintes enclosing several hectares and with projecting towers at the corners and along the sides (Mattingly and Sterry 2013; Sterry and Mattingly 2011 ; 2013). The date of such fortifications at Garamantian sites of the third to sixth centuries $\mathrm{AD}$ is supported by a large number of AMS dates (Sterry and Mattingly 2013; Sterry et al. 2012). Two particular cases of Garamantian urban fortifications might serve as examples for what the Banu Khattab rulers did at Zuwila. These were the forts that were built at the heart of the urban sites of Jarma and Qasr ash-Sharraba (Figure 16b). The latter was a large fort (c. 1 ha) of somewhat similar appearance to the Zuwila fortress, though with fewer and slightly less regularly spaced projecting towers. Interestingly, there was an inner citadel in the north-east corner of the enceinte, also of Garamantian date, in exactly the same position as the later qasabab at Zuwila, which we have postulated may overlie an early palace/citadel. At Jarma, we have reconstructed evidence for a central qasr, probably less than 0.25 ha in area, of a type familiar to other Garamantian villages like GBD001, HHG001, HHG006-008 and Garamantian Zuwila itself (see Figure 16b). Returning to Zuwila, there was in fact just such a fortified qasr of probable Garamantian date at the centre of the unenclosed settlement a few hundred metres to the south-east of the enceinte discussed in this article.

However, despite these apparent similarities between Garamantian urbanism and the architectural layout of major settlements, there are significant novelties in the case of the Zuwila walls that suggest that external influences were in fact more significant here. What most plainly differentiates the tenth- or early eleventh-century Zuwila fortress from these Garamantian fortified structures is its size in area and height, the unusual mode of construction and 


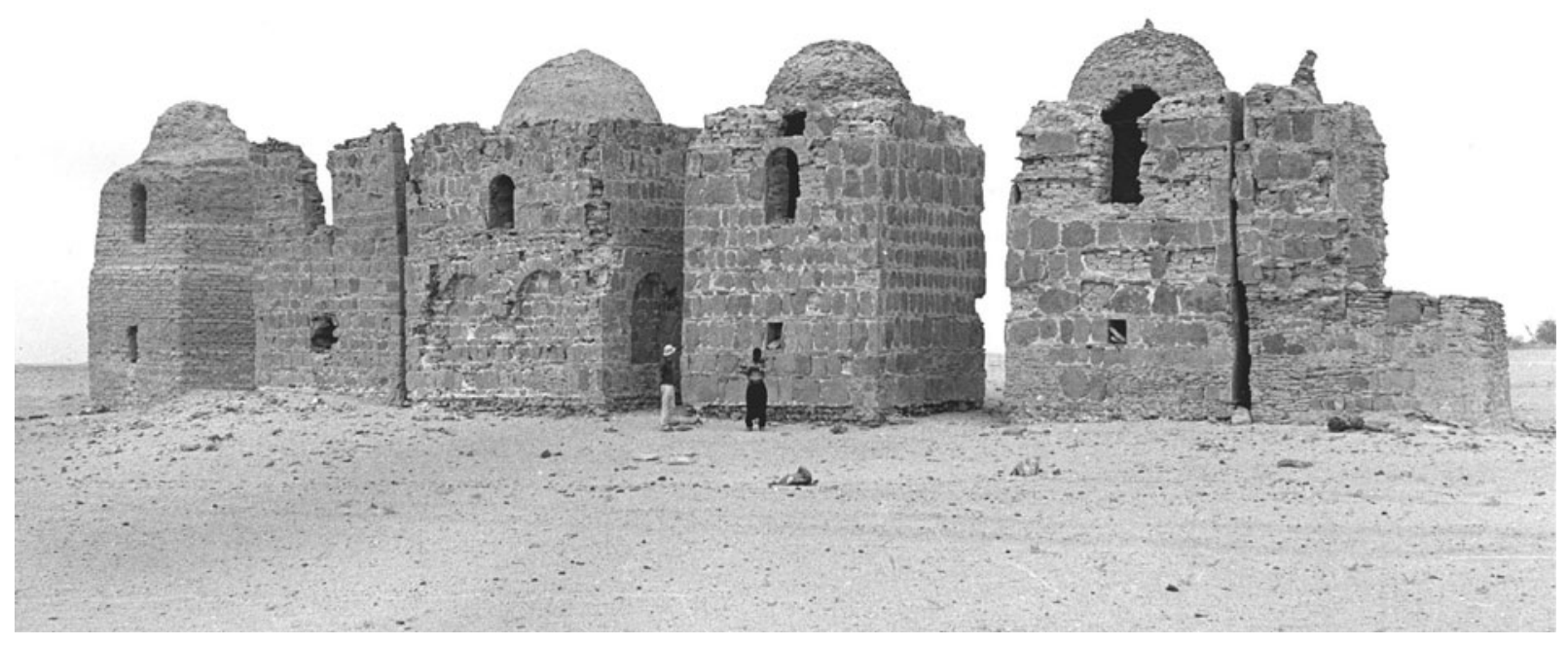

Figure 17. The 'ashlar effect' walls of the tombs of the Banu Khattab (ZUL003). Sadly, these tombs were blown up by Islamic extremists in 2013.

its placement outside, but still dominating, a preexisting settlement.

The most common traditional methods of wall construction in Fazzan have involved either regularly formed mudbricks or, in more recent centuries, irregular lumps of salt enriched mud bonded with mud mortar. There are some possible traces of small pisé walls from the Fazzan Project excavations at Jarma (Mattingly 2013, 160), but these were very much in the minority and Garamantian fortifications seem almost exclusively to have been built with mudbricks (or, exceptionally, the stone qasr at Larcu; Mattingly 2007, 196-97). Compacted earth construction is more common in sub-Saharan regions (Insoll 1997, 9; Schiffer 1987, 226-27), but it is also known from Punic and Roman times onwards in the Maghreb (Fentress 2001, 257-60). While we do not know of examples of rammed earth fortifications on the scale of the Zuwila walls in Roman North Africa, this form of construction was evidently much more common in the Islamic Maghreb (especially in Morocco and Algeria). In southern Morocco in medieval and early modern times pisé construction has been virtually ubiquitous, not only for urban enceintes and large qasabahs, but also for smaller dwellings and even garden walls (though comparatively few structures are closely datable). A southern Moroccan origin for large-scale pisé construction is not implausible, not least as there is some evidence to suggest the export of the construction method from there through Moorish expansion into Spain. There are some pisé constructions in the Iberian peninsula dated to the ninth and tenth centuries (Jaquin et al. 2008).
The southern Moroccan sites in particular have significant structural similarities with Zuwila's walls (Nami et al. 2014, 69-83). Pisé walls had the advantage of being relatively quick and comparatively cheap to construct. In the sometimes unsettled conditions of the Arab conquest of the Maghreb and the subsequent rise of new dynasties in Morocco there were pragmatic reasons behind the frequent construction of fortress towns (Bennison 2007; Bloom 2000; Fenwick 2013; Kennedy 2010; Marçais 1955). Morocco appears to have been a particularly intense focus for Islamic urban development, with the rise there of the Almoravid and Almohad dynasties (Cressier and García-Arenal 1998; Cressier and Erbati 2008; O’Meara 2007). Also potentially important were the schismatic groups like the Rustamids at Tahert in Algeria or the Ibadis at Zuwila and elsewhere. The possibility that the Zuwila walls were inspired by such long-range contacts across Ifriqiyya (and arguably built by a core team who had significant prior experience with the construction method) is extremely interesting and potentially important for our wider understanding of this turbulent era. The construction of the pisé walls at Zuwila thus provides additional support to the literary tradition of an Ibadi migration from outside Fazzan in the tenth century, but this evidence demonstrates that the connections of the Ibadis at Zuwila went far beyond the Jabal Nafusa area in Tripolitania to the north of Fazzan. The construction technique emphasises the importance of the Saharan links of the Ibadis. It would be interesting to know more archaeologically about the Rustamid centres of Tahert and Sedrata or to have a clearer 
chronology for the early use of pisé in southern Morocco.

Our knowledge of early Islamic architecture in Libya is fairly scanty, but the best-known sites of Madinat Sultan (Surt) and Ajdabiya look very different in character and we know of no other use of massive pisé construction in the region (Kenrick 2009; 2013; Sjöström 1993). The Banu Khattab were refugees from a failed rebellion against the Arab rulers of Tripolitania and Ifriqiyya (Rossi 1968), but the architectural reference points for the monuments of the Banu Khattab are more Saharan than Tripolitanian (the Jabal Nafusa being the northern heartland of the Ibadis). Their links with much more remote Maghrebian and Saharan centres of Ibadi resistance thus appear to have been significant. The adoption of new forms of construction for the fortress walls and new architectural models (as the tombs of the Banu Khattab plainly were) reveals a self-confident Islamic state in the Libyan Sahara that was breaking with long-established local traditions. The Zuwila walls took such expressions of power to another level in terms of scale. The tombs of the Banu Khattab sought to convey the impression of ashlar stone monuments, though in the absence of suitable local stone the effect was achieved by sheathing mudbrick structures with thin slabs of stone (see Figure 17). What happened at Zuwila in the tenth century, we suggest, was the creation of a new architecture of power and authority by an Islamic Saharan state. The comparatively short-lived nature of the Banu Khattab state and its relative isolation limited the spread of such extraordinary architecture more widely within the Libyan Sahara. Nonetheless, the brief and singular appearance of large-scale pisé construction at Zuwila raises important new questions about the connections of the Ibadis within a wider Saharan world and about what came after. It also highlights the need for dating of key features, such as defences, at a far wider range of Saharan sites (Sterry and Mattingly 2013; Sterry et al. 2012).

\section{Acknowledgements}

This article is an output of the Trans-Sahara Project, funded by the European Research Council (grant 269418). The research draws on the unpublished papers and photographs of the late Charles Daniels held in the Archive of the Society for Libyan Studies at the University of Leicester. Charles is rightly named as a co-author of the resulting paper. Other members of his team involved in the survey work at Zuwila in 1968 were Patrick Carmody and Jack Tait. Work by the Fazzan Project at Zuwila in 1998 and 2001 was funded by the Society for Libyan Studies and involved David Mattingly, Jamie Preston, Sophie Hay, Toby Savage, and John Dore. The samples for AMS dating were taken at the request of the Controller of Fazzan, Dr Ali Abu Salim, and dated at the Oxford Radiocarbon Laboratory, where we are grateful to Tom Higham for his advice and support of our dating programme. Two referees provided some extremely valuable suggestions and saved us from some egregious errors. We are particularly grateful to Corisande Fenwick for pointing us towards some key literature on early Islamic urbanism. Needless to say, we alone remain responsible for the views expressed.

\section{References}

Abdussaid, A. 1979. The excavations of Zwela Mosque. Libya Antiqua 15/16: 327-29.

Bennison, A.K. 2007. Power and the city in the Islamic west from the Umayyads to the Almohads. In A. K. Bennison and A.L. Gascoigne (eds), Cities in the Pre-Modern Islamic World: The Urban Impact of Religion, State and Society. Routledge, Abingdon: 65-95.

Bloom, J.M. 2000. Walled cities in Islamic North Africa and Egypt with particular reference to the Fatimids (909-1171). In J.D. Tracy (ed.), City Walls: The Urban Enceinte in Global Perspective. Cambridge University Press, Cambridge: 219-46.
Bruce-Lockhart, J., and Wright, J. (eds.) 2000. Difficult and Dangerous Roads: Hugh Clapperton's Travels in Sahara and Fezzan 1822-1825. Sickle Moon Books, London.

Cressier, P., and Erbati, L. 2008. Le pouvoir dans ses murs. Villes et fortifications dans le Maroc du haut Moyen Age. In P. Cressier (ed.), Le chateau et la ville. Espace et réseaux. Casa de Velázquez, Madrid: 283-97.

Cressier, P., and García-Arenal, M. 1998. Genèse de la ville islamique en al-Andalus et au Maghreb occidental. Casa de Velázquez, Madrid.

Daniels, C.M. 1968. The Garamantes of Fezzan. An interim report of work carried out by the 1968 expedition to Fezzan, Libya. Unpublished typescript, 4 pp. 
Daniels, C.M. 1989. Excavation and fieldwork amongst the Garamantes. Libyan Studies 20: 45-61.

Despois, J. 1946. Mission scientifique du Fezzan (1944-1945) III Géographie humaine. Omp. Imbert, Algiers.

Edwards, D. 2001. Archaeology in the southern Fazzan and prospects for future research. Libyan Studies 32: 49-66.

Fentress, E. 2001. Villas, wine and kilns: the landscape of Jerba in the late Hellenistic period. Journal of Roman Archaeology 14: 249-68.

Fenwick, C. 2013. From Africa to Ifriqiya: settlement and society in early medieval North Africa (650800). Al-Masaq 25.1: 9-33.

Gigliarelli, U. 1932. Il Fezzan. Governo della Tripolitania, Tripoli.

el-Hesnawi, H.W. 1990. Fazzan Under the Rule of the Awlad Muhammad. A Study in Political, Economic, Social and Intellectual History. University of Sabha, Sabha.

Hornemann, F. 1802. The Journal of Frederick Hornemann's Travels from Cairo to Mourzouk the Capital of the Kingdom of Fezzan in Africa in the Years 1797-9. 1985 reprint. Darf Publishers, London and Tripoli.

Insoll, T. 1997. Iron Age Gao: an archaeological contribution. Journal of African History 38.1: 1-30.

Jaquin, P.A., Augarde, C.E., and Gerrard, C.M. 2008. Chronological description of the spatial development of rammed earth techniques. International Journal of Architectural Heritage 2.4: 377-400.

Kennedy, H. 2010. How to found an Islamic city. In C. Goodson, A.E. Lester, and C. Symes (eds), Cities, Texts, and Social Networks, 400-1500: Experiences and Perceptions of Medieval Space. Ashgate, Farnham: 45-64.

Kenrick, P. 2009. Libya Archaeological Guides: Tripolitania. Society for Libyan Studies, London.

Kenrick, P. 2013. Libya Archaeological Guides: Cyrenaica. Society for Libyan Studies, London.

Levtzion, N., and Hopkins, J.F.P. 2000. Corpus of Early Arab Sources for West African History. Princeton University Press, Princeton.

Lyon, G.F. 1821. A Narrative of Travels in Northern Africa in the Years 1818-1819 and 1820. 1966 reprint. Frank Cass, London.

Marçais, G. 1955. L'architecture musulman d'occident: Tunisie, Algérie, Maroc, Espagne et Sicilie. Arts et Metiers, Paris.

Mattingly, D.J. (ed.) 2003. The Archaeology of Fazzān. Volume 1, Synthesis. Department of Antiquities, Tripoli; Society for Libyan Studies, London.
Mattingly, D.J. (ed.) 2007. The Archaeology of Fazzān. Volume 2, Site Gazetteer, Pottery and other Survey Finds. Department of Antiquities, Tripoli; Society for Libyan Studies, London.

Mattingly, D.J. (ed.) 2013. The Archaeology of Fazzān. Volume 4, Survey and Excavations at Old Jarma (Ancient Garama) carried out by C. M. Daniels (1962-69) and the Fazzān Project (1997-2001). Department of Antiquities, Tripoli; Society for Libyan Studies, London.

Mattingly, D.J., and Sterry, M. 2013. The first towns in the Central Sahara. Antiquity 87.366: 503-18.

Mattingly, D.J., Sterry, M., and Edwards, D. 2015. The origins and development of Zuwīla, Libyan Sahara: an archaeological and historical overview. Azania 50.1: 27-75.

Messier, R.A. 1997. Sijilmasa. Five seasons of archaeological inquiry by a joint Moroccan-American Mission. Archéologie Islamique 7: 61-92.

Nami, M., Belatik, M., and Atki, M. 2014. De Foum Zguid à Foum el Hisn. Inventaire du patrimoine culturel de Tata. Publication du Ministère de la Culture, Bilnet.

O’Meara, S. 2007. The foundation legend of Fez and other Islamic cities in light of the life of the Prophet. In A.K. Bennison and A.L. Gascoigne (eds), Cities in the Pre-Modern Islamic World: The Urban Impact of Religion, State and Society. Routledge, Abingdon: 27-41.

Pace, B., Sergi, S., and Caputo, G. 1951. Scavi sahariani. Monumenti Antichi 41: 150-549.

Rossi, E., 1968. Storia di Tripoli e della Tripolitania dalla conquista araba al 1911. Istituto per l'Oriente, Rome.

Scarin, E. 1934. Le oasi del Fezzan. 2 vols. Zanicelli, Bologna.

Scarin, E. 1937a. Insediamenti e tipi di dimore. In Il Sahara Italiano, I. Fezzan e oasi di Gat. Società Italiana arto grafiche, Rome: 515-60.

Scarin, E. 1937b. Descrizione delle oasi e gruppi di oasi. In Il Sahara Italiano, I. Fezzan e oasi di Gat. Società Italiana arto grafiche, Rome: 603-44.

Schiffer, M.B. 1987. Formation Processes of the Archaeological Record. University of New Mexico Press, Albuquerque.

Sjöström, I. 1993. Tripolitania in Transition: Late Roman to Islamic Settlement: With a Catalogue of Sites. Avebury, Aldershot.

Sterry, M., and Mattingly, D.J. 2011. DMP XIII: reconnaissance survey of archaeological sites in the Murzuq area. Libyan Studies 42: 103-16.

Sterry, M., and Mattingly, D.J. 2013. Desert Migrations Project XVII: further AMS dates for historic settlements from Fazzān, south-west Libya. Libyan Studies 44: 127-40. 
Sterry, M., Mattingly, D.J., and Higham, T. 2012. Desert Migrations Project XVI: radiocarbon dates from the Murzuq region, southern Libya. Libyan Studies 43: 137-47.

Thiry, J. 1995. Le Sahara libyen dans l'Afrique du nord médiévale. Orientalia Lovaniensia Analecta 72. Peeters, Leuven.
Ziegert, H. 1969. Überblick zur jüngeren Besiedlungsgechichte des Fezzan. Berliner Geographischen Abhandlungen 8: 49-58.

Ziegert, H., and Abdussalam, A. 1973. The white mosque of old Zuila. Libya Antiqua 9-10: 221-22.

Zoli, C. 1926. Nel Fezzan. Note e impressioni di viaggio. Alfieri e Lacroix, Milan. 